\title{
Modulation of Reactive Oxygen Species and Collagen Synthesis by Angiotensin II in Cardiac Fibroblasts
}

\author{
Paul J. Lijnen ${ }^{*}$, , John S. Prihadi ${ }^{1}$, Jos F. van Pelt ${ }^{2}$ and Robert H. Fagard ${ }^{1}$ \\ ${ }^{1}$ Hypertension and Cardiovascular Rehabilitation Unit, Department of Cardiovascular Diseases and ${ }^{2}$ Laboratory of \\ Hepatology, Department of Pathophysiology, Katholieke Universiteit Leuven (K.U.Leuven), Belgium
}

\begin{abstract}
Angiotensin II increases the NAD(P)H-dependent superoxide anion production and the intracellular generation of reactive oxygen species in cardiac fibroblasts and apocynin, a NAD $(\mathrm{P}) \mathrm{H}$ oxidase inhibitor, abrogates this rise. The membrane associated $\mathrm{NAD}(\mathrm{P}) \mathrm{H}$ oxidase complex is the predominant source of superoxide anion and reactive oxygen species generation in angiotensin II-stimulated adult cardiac fibroblasts. Inhibition of this NAD(P)H oxidase complex with apocynin completely blocks the angiotensin II-stimulated collagen production, collagen I and III protein and mRNA expression.

Superoxide anion production is also increased by the $\mathrm{Cu}, \mathrm{Zn}$-superoxide dismutase (SOD) inhibitor diethyldithiocarbamic acid (DETC) and decreased by the superoxide scavenger tempol in control and ANG II-treated fibroblasts. ANG II and DETC stimulate the collagen production and the collagen I and fibronectin content in fibroblasts. The SOD mimetics tempol and EUK-8 as well as polyethyleneglycol-SOD reduce the collagen production.

ANG II also decreases the activity and mRNA and protein expression of the mitochondrial antioxidants Mn-SOD and peroxiredoxin-3. Upon phosphorylation of Akt by ANG II, P-Akt is translocated from the cytoplasm to the nucleus and nuclear phosphorylation of FOXO3a by P-Akt leads to relocalisation of FOXO3a from the nucleus to the cytosol, resulting in a decrease in its transcriptional activity and in Mn-SOD expression. These data indicate that ANG II inactivates FOXO3a by activating Akt and this leads to a reduction in the expression of the antioxidant Mn-SOD. A role of SOD and the formed reactive oxygen species in the regulation and organization of collagen in cardiac fibroblasts is suggested.
\end{abstract}

Keywords: Cardiac fibroblasts, angiotensin II, reactive oxygen species, collagen, superoxide dismutases, peroxiredoxins, FOXO3a.

\section{INTRODUCTION}

Increased oxidative stress has been shown in the pericardial fluid formed by the myocard of patients and animals with heart failure [1,2] and antioxidants attenuate the development of myocardial failure [3]. Hypertension is also associated with an elevation of reactive oxygen species (ROS) and frequently with an impairment of endogenous antioxidant mechanisms [4-6]. The elevation of blood pressure by oxidants and its amelioration by antioxidants strongly supports a role of ROS in hypertension [6]. During the development of hypertension, ROS are generated by endogenous sources, notably the $\mathrm{NAD}(\mathrm{P}) \mathrm{H}$ oxidase enzyme family and uncoupled nitric oxide synthase [6].

In hypertension there is a mutual reinforcement between ROS and angiotensin II (ANG II) [6]. Effects of ANG II are related to the oxidative stress. Indeed, oxidative stress is increased in mice after infusion of ANG II [7, 8]. ANG II also induces oxidative stress in vitro, increasing ROS in various types of cultured cells such as vascular smooth muscle cells from rat thoracic aorta [9], adult cardiac microvas-

*Address correspondence to this author at the Hypertension Unit, K.U.Leuven, Campus Gasthuisberg, Herestraat 49, P.O. Box 702, 3000 Leuven, Belgium; Tel: 32016 345766; Fax: 32016 346203; E-mail: paul.lijnen@med.kuleuven.be cular endothelial cells [10], neonatal rat cardiac myocytes $[11,12]$ and human hepatic stellate cells [13]. It has also been extensively demonstrated that ANG II markedly increases vascular NAD $(\mathrm{P}) \mathrm{H}$ oxidase activity [9,14-18].

Antioxidant enzymes such as superoxide dismutase (SOD), catalase and peroxidases regulate reactive oxygen species by maintaining superoxide anion $\left(\mathrm{O}_{2}{ }^{-}\right)$and hydrogen peroxide $\left(\mathrm{H}_{2} \mathrm{O}_{2}\right)$ at low levels. A chronic increase in ROS in the myocard, possibly due to impairment of SOD or other antioxidant pathways, could contribute to myocardial remodeling and failure [2, 19]. SODs, catalase, glutathione peroxidases and peroxiredoxins constitute the principal components of the antioxidant defense system and their deficiencies can cause oxidative stress. In mammalian tissue three isoforms of SOD have been identified and differ in their location. $\mathrm{Cu} / \mathrm{Zn}-\mathrm{SOD}$ constitutes $90 \%$ of total tissue [20] and is localized in the cytosol, Mn-SOD in the mitochondria and extracellular SOD in the interstitial fluid [21]. Inhibition of endogenous SOD by the specific inhibitor diethyldithiocarbamic acid (DETC), a copper chelator, increases basal $\mathrm{O}_{2}^{-}$production in aorta rings of normal and spontaneously hypertensive rats [22] and in rings of rabbit thoracic aorta [23]. An enhancement of " $\mathrm{O}_{2}{ }^{-}$generation by DETC is also shown in neonatal rat cardiac myocytes [12] and fibroblasts [24]. The angiotensin II- induced NADPH dependent $\mathrm{O}_{2}{ }^{-}$production is higher in DETC-treated vascular 
smooth muscle cells than in control cells [25]. In skin fibroblasts SOD reduces transforming growth factor- $\beta_{1}$ and collagen type I mRNA expression [26]. SOD also strongly colocalizes with type I collagen in the extracellular matrix of blood vessels [27]. Human aortic SOD also binds collagen type I [28]. Its association with collagen is important in protecting it from oxidative fragmentation [29].

Both, ANG II and oxidative stress induce collagen in vivo and in vitro. Oxidative stress induces remodeling of the myocard $[7,11,12,30]$ and regulates collagen metabolism in a variety of noncardiac cells, such as lung and skin fibroblasts and human venous endothelial cells [31-33]. In addition to oxidative stress infusion of ANG II induces severe cardiac fibrosis [34]. Moreover, an ANG II-induced increase in collagen production has also been demonstrated in various types of cultured cells such as rat vascular smooth muscle cells [35], murine mesangial cells [36, 37], rat glomerular cells [38] and adult rat cardiac fibroblasts [39-42].

In this review paper we will discuss if inhibition of the catalytic and regulatory subunits of $\mathrm{NAD}(\mathrm{P}) \mathrm{H}$ oxidase with apocynin or diphenyleneiodonium chloride (DPI) affects the collagen production and expression in adult rat cardiac fibroblasts and if ANG II stimulates $\mathrm{NAD}(\mathrm{P}) \mathrm{H}$ oxidase in these cells through a redox sensitive mechanism. The contribution of the activity of SOD in the ${ }^{\cdot} \mathrm{O}_{2}{ }^{-}$generation and intracellular ROS production in control and angiotensin IIstimulated cardiac fibroblasts from adult rats will also be discussed as well as its involvement in the induction of protein and mRNA expression of collagen type I and III and fibronectin. SOD is irreversibly inhibited by the copper chelator DETC and its effect is compared with tempol, a stable membrane-permeable metal-independent SOD mimetic that is specific for ${ }^{-} \mathrm{O}_{2}{ }^{-}$and with 4-carboxy-tempol, a structural related and inactive compound of tempol who has minimal $\mathrm{O}_{2}{ }^{-}$scavenging activity.

\section{ANG II-INDUCED COLLAGEN PRODUCTION AND DEGRADATION DURING INHIBITION OF CARDIAC FIBROBLAST SUPEROXIDE GENERA- TION}

ANG II dose-dependently increases collagen production in adult rat cardiac fibroblasts in culture (Fig. 1) and this effect is blocked by the ANG II $\mathrm{AT}_{1}$-receptor antagonist telmisartan, but not by the $\mathrm{AT}_{2}$-receptor antagonist, $\mathrm{P}-186$ [43].

Besides the stimulation of collagen synthesis, ANG II also increases mRNA levels of collagen type I, type III, pro$\alpha_{1}$ (III) collagen and fibronectin in cultured cardiac fibroblasts [40,41,43-45]. The ANG II-induced expression of type I collagen mRNA is also completely abolished by $\mathrm{AT}_{1-}$ receptor antagonism but is unaffected by $\mathrm{AT}_{2}$-receptor antagonism [40,44,46,47]. In vivo, ANG II infusions at pressor or subpressor doses in rats also induces an increase in collagen and fibronectin [48, 49].

The presence of high numbers of ANG II $\mathrm{AT}_{1}$-receptors on neonatal and adult rat cardiac fibroblasts has been documented [40, 41, 50-52]. $\mathrm{AT}_{1}$-receptors exhibit saturable, reversible and high-affinity binding of ANG II, that is competed for by nonpeptide $\mathrm{AT}_{1}$ receptor antagonists, $\mathrm{ANG}$ I and ANG III. Competitive binding studies employing nonpeptide antagonists for $\mathrm{AT}_{2}$-receptors fail to detect their presence in either neonatal or adult cardiac fibroblasts [40, $41,51]$ although ANG II inhibition of collagenase activity in adult rat cardiac fibroblasts is attenuated only by $\mathrm{AT}_{2}$ receptor blockade [42].

Of the two $\mathrm{AT}_{1}$-receptor subtypes expressed in the rat, cardiac fibroblasts express much higher mRNA levels for the $\mathrm{AT}_{1 \mathrm{~A}}$ than the $\mathrm{AT}_{1 \mathrm{~B}}$ receptor [52]. Adult rat cardiac fibroblasts express higher mRNA levels for the $\mathrm{AT}_{1}$-receptor than do neonatal cardiac fibroblasts. The expression of ANG II

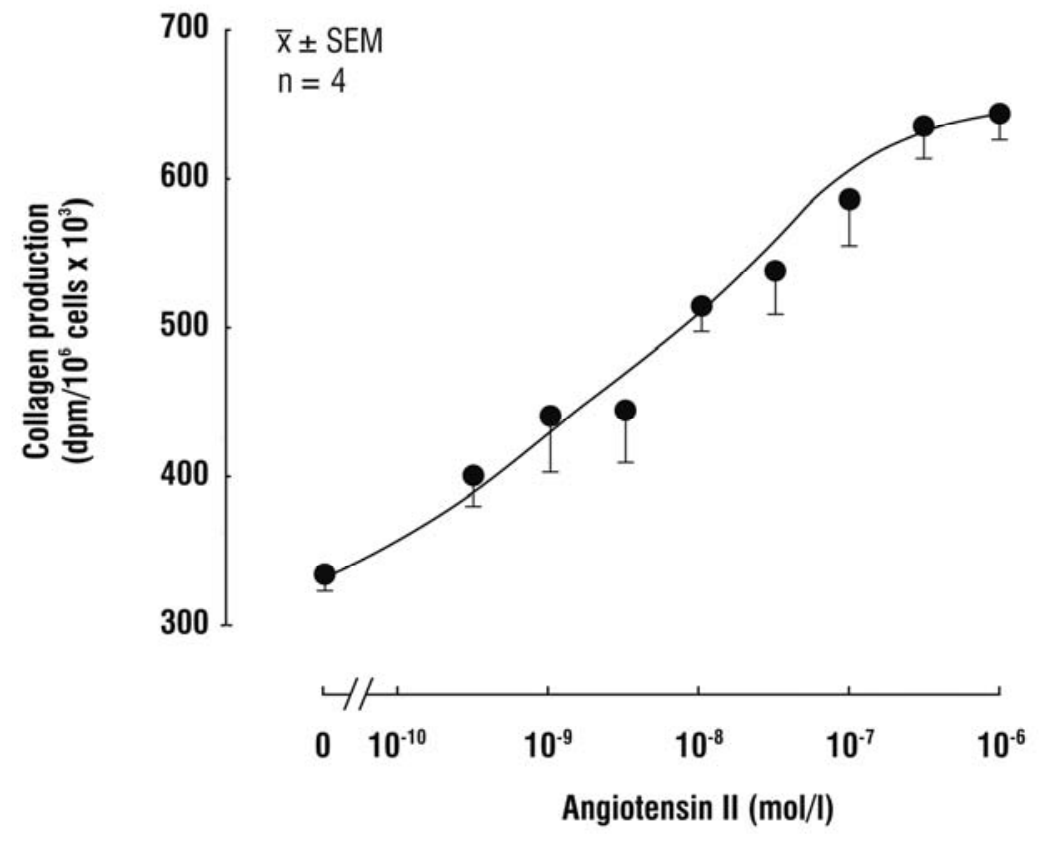

Fig. (1). Concentration-response curve for ANG II-induced changes in collagen production in adult rat cardiac fibroblasts. 
receptors by left ventricular fibroblasts exhibits, however, marked species dependence. Cultured rat fibroblasts express 43,000 $\pm 15,000$ ANG II (AT ${ }_{1}$-specific) receptors per cell, whereas rabbit and neonatal human cardiac fibroblasts express fewer such receptors [53]. However, in isolated human cardiac fibroblasts, ANG II itself does not increase collagen I mRNA directly but through indirect pathways that may involve TGF- $\beta_{1}$ and osteopontin [54].

The ability of ANG II to induce collagen synthesis and expression of collagen in rat cardiac fibroblasts may be mediated by an increased TGF- $\beta_{1}$ production in an autocrine/ paracrine fashion. Indeed, cardiac fibroblasts are the principal cellular origin of TGF- $\beta_{1}$ and in cultured rat adult cardiac fibroblasts ANG II stimulates TGF- $\beta_{1}$ gene expression, increases total TGF- $\beta_{1}$ production and promotes the conversion of latent TGF- $\beta_{1}$ to the active form [50,55-59]. Simultaneous treatment of cardiac fibroblasts in vitro with ANG II and a neutralizing antibody to TGF- $\beta_{1}$ reduces type I and type III collagen mRNA expression [59] and collagen production (Fig. 2).

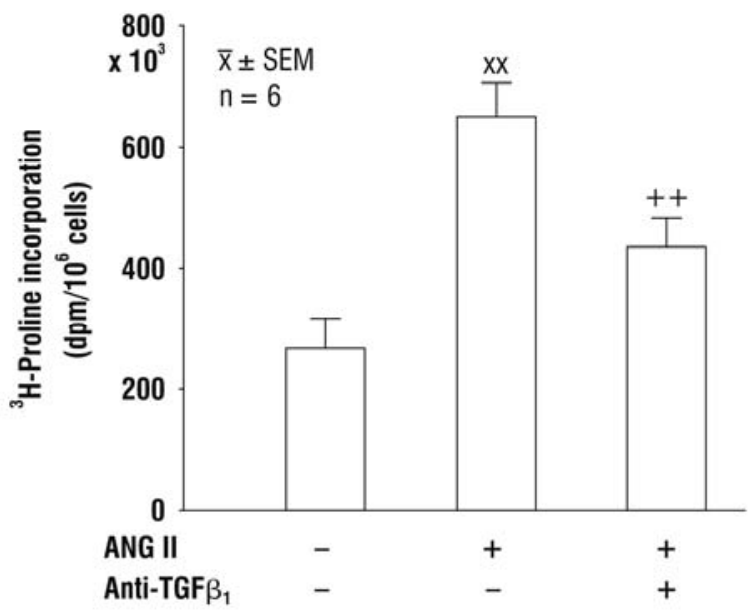

Fig. (2). Collagen production, assessed as $3 \mathrm{H}$-proline incorporation, in cardiac fibroblasts treated with(out) ANG II $(1 \mu \mathrm{mol} / \mathrm{l})$ and a neutralizing antibody to transforming growth factor-1 (anti-TGF-1, $10 \mu \mathrm{g} / \mathrm{ml}$ ) for 24 hours. $\mathrm{xx} \mathrm{p}<0.01$ compared to control; $++\mathrm{p}<0.01$ compared to ANG II.

ANG II-stimulated TGF- $\beta_{1}$ secretion is greatly attenuated by a $\mathrm{AT}_{1}$-receptor antagonist [60]. We [61] have also demonstrated that TGF- $\beta_{1}$ induces the differentiation of cardiac fibroblasts to myofibroblasts and this differentiation is accompanied by an increase in angiotensin converting enzyme (ACE) activity and protein and by a profound modification of the fibroblast phenotype, which consists of a change in cell morphology, an enlargement of cell volume and an increase in cell protein content [62]. Moreover the effects of ANG II and TGF- $\beta_{1}$ are also complimentary in vivo. Both of them induce cardiac fibrosis which, independent of the primary stimulus, is accompanied by high tissue concentrations of both ANG II and TGF- $\beta_{1}$ [63-65]. Both TGF- $\beta_{1}$ and ACE, as a means of ANG II synthesis, are thus involved in the enhancement of cardiac tissue fibrosis and these factors can create a vicious circle in the fibrotic tissue [66].
The ANG II-stimulated soluble collagen production in cultured adult rat cardiac fibroblasts is completely blocked by the NAD $(\mathrm{P}) \mathrm{H}$ oxidase inhibitors apocynin and DPI (Fig. 3) [67].
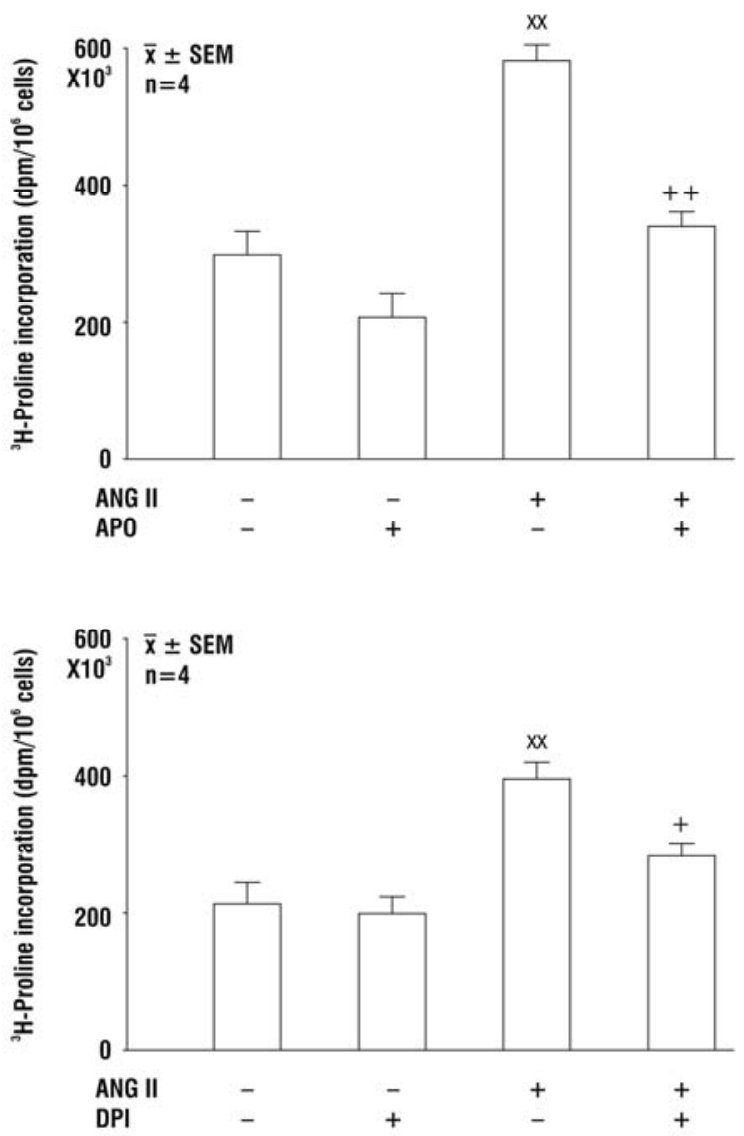

Fig. (3). Effect of apocynin (APO, $100 \mu \mathrm{mol} / \mathrm{l}$ ) and diphenyleneiodonium chloride (DPI, $2 \mu \mathrm{mol} / \mathrm{l}$ ) on soluble collagen production in cardiac fibroblasts treated with(out) Ang II $(1 \mu \mathrm{mol} / \mathrm{l})$ for 24 hours. $\mathrm{xx} p<0.01$ compared with control without ANG II, APO and DPI; ++ p<0.01, + p $<0.05$ compared with samples with ANG II and without APO and DPI.

Apocynin is considered an inhibitor of the association of $\mathrm{p} 47^{\text {phox }}$ and $\mathrm{p} 67^{\text {phox }}$ with a gp91 ${ }^{\text {phox }}$ (or Nox2) homologue subunit within the membrane $\mathrm{NAD}(\mathrm{P}) \mathrm{H}$ oxidase complex [68]. DPI inhibits $\mathrm{NAD}(\mathrm{P}) \mathrm{H}$ oxidase by binding to the cellular flavoprotein moiety of the complex [69]. It should however be taken into consideration that DPI is a flavoenzyme inhibitor and not specific for NADPH oxidase, inhibiting other flavoenzymes as well. In addition, it can not be said that apocynin is specific for NADPH oxidase since apocynin has also antioxidant effects. Because the hemodynamic stress of hypertension can be excluded in these in vitro culture conditions, it can be assumed that the presence of ANG II and associated ROS generation is the basis of enhanced collagen synthesis by cardiac fibroblasts.

In vitro, inhibition of a membrane as well as a cytosolic component of the NAD $(\mathrm{P}) \mathrm{H}$ oxidase complex suppresses the ANG II-stimulated collagen production in adult rat cardiac 
fibroblasts in culture [67]. In contrast, inhibition of xanthine oxidase, cyclooxygenase, lipoxygenase, the respiratory chain, cytochrome P450 mono-oxygenase and NO synthase has no effect on ANG II-induced collagen production in cardiac fibroblasts [67]. The demonstration that apocynin and DPI block the ANG II-stimulated collagen production suggests that the predominant source of cardiac fibroblast superoxide generation is the membrane-associated $\mathrm{NAD}(\mathrm{P}) \mathrm{H}$ oxidase complex.

ANG II-stimulated collagen production is also associated with an increase in both the mRNA and the protein expression of collagen type I and III [67]. The synthesis of collagen in cardiac fibroblasts is thus regulated at the transcriptional and posttranslational level.

However, the extracellular matrix collagen content depends not only on its production but also on its degradation by enzymes such as MMP-1. In adult rat cardiac fibroblasts ANG II stimulates collagen production and regulates collagen degradation by attenuating MMP-1 and through enhancing TIMP-1, the tissue inhibitor of MMP-1 [67]. The decrease in MMP-1 and the increase in TIMP-1 induced by ANG II in cardiac fibroblasts would result in less collagen degradation and favors collagen synthesis, explaining at least partly the profibrotic effect of ANG II on the myocard in various pathophysiological conditions where the renin angiotensin system is activated. Brilla et al. [42] first showed that ANG II decreased the collagenase activity in adult rat cardiac fibroblasts. In TNF $\alpha$-stimulated neonatal rat cardiac fibroblasts, ANG II increases TIMP-1 expression and decreases MMP-2 activity [70].

However, ANG II affects MMP expression/activity differently in various cell types. An enhanced MMP activity and expression is reported in endothelial cells [71], cardiac myocytes [72] and in skin fibroblasts [73]. In cardiac fibroblasts the effect of ANG II on collagen synthesis, MMP-1 and TIMP-1 content is completely blocked by apocynin suggesting that ROS generated through the membraneassociated $\mathrm{NAD}(\mathrm{P}) \mathrm{H}$-oxidase are involved in the fibrotic process.

In vivo experiments have shown that apocynin reduces systolic blood pressure and prevents the increase in media/ lumen ratio, endothelial dysfunction and collagen deposition in the media of mesenteric resistance arteries from ANG IIinfused mice [74]. ANG II also increases significantly cardiac collagen content in wild type but not in $\mathrm{gp} 91^{\text {phox--/- }}$ mice [11], indicating that in vivo deletion of Nox2 reduces ANG II-induced cardiac fibrosis. Indeed, Nox2 is required for ANG II-induced cardiac fibrosis in rodents [11].

In salt-loaded, aldosterone-infused rats apocynin prevents collagen deposition in the perivascular regions of the left ventricle, decreases the aortic mRNA level of procollagen I, procollagen III and $\mathrm{p} 22^{\text {phox }}$, inhibits $\mathrm{NAD}(\mathrm{P}) \mathrm{H}$ oxidase activity, normalizes cardiac hypertrophy and reduces systolic blood pressure [75-77]. Inhibition of $\mathrm{NAD}(\mathrm{P}) \mathrm{H}$ oxidase activity by gp91ds-tat, a chimeric peptide that inhibits $\mathrm{p} 47^{\text {phox }}$ association with $\mathrm{gp} 91^{\text {phox }}$ in $\mathrm{NAD}(\mathrm{P}) \mathrm{H}$ oxidase, attenuates blood pressure increase, regresses cardiac and vascular remodeling and improves endothelial function in ANG II-infused rodents, as does apocynin [20,78]. The increased collagen volume fraction of the ventricles of aldosterone-treated rats is also prevented by cotreatment with the antioxidant $\mathrm{N}$-acetyl cysteine or pyrolidine dithiocarbamate which also abrogates the aldosterone-induced $\mathrm{NAD}(\mathrm{P}) \mathrm{H}$ oxidase and $\mathrm{NF}-\mathrm{\kappa B}$ activation [79]. Iglarz et al. [80] have shown that aldosterone infusion induces a significant increase of interstitial cardiac fibrosis in terms of collagen deposition in the mid-myocard which is prevented by the superoxide dismutase mimetic tempol. The profibrotic action of aldosterone is mediated, at least in part, by ROS generation and involves an interaction with the reninangiotensin system. Inhibition of ANG II-induced ROS generation in cardiac fibroblasts by the peroxisome-activated receptor- $\boldsymbol{\gamma}$ ligand, pioglitazone, is also associated with a concomitant inhibition of ANG II-stimulated collagen production [81]. In hypertensive rats with activation of the renin-angiotensin system, apocynin also attenuates hypertension and increases the antioxidant defenses glutathione peroxidases and glutathione-S-transferase [82].

Taking these in vitro and in vivo data together suggest that myocardial accumulation of collagen and/or the deposition of collagen in cardiac fibroblasts is, at least partly, mediated by activation of $\mathrm{NAD}(\mathrm{P}) \mathrm{H}$ oxidase and that blockade of ROS at the level of NAD $(\mathrm{P}) \mathrm{H}$ oxidase may exert beneficial effects on the heart as well as large arteries in hypertension associated with oxidative stress.

\section{ANG II-INDUCED ROS GENERATION AND MODULATION BY APOCYNIN}

Quiescent rat cardiac fibroblasts treated with ANG II for 24 hours demonstrate $\mathrm{NAD}(\mathrm{P}) \mathrm{H}$ oxidase activity that was $180 \pm 11 \%$ of vehicle control; this activity is inhibited by coincubation with apocynin [67]. These findings are in accordance with the stimulation $(165 \pm 19 \%)$ of $\mathrm{NAD}(\mathrm{P}) \mathrm{H}$ oxidase by ANG II in quiescent rat aortic fibroblasts and the reduction by gp91ds-tat [78].

In cultured adult rat cardiac fibroblasts the specificity of the oxidase is found for NADH and not for NADPH [67]. In human fetal lung fibroblasts [83] NADH is also reported to be a better substrate than NADPH for superoxide-generating oxidases. A superoxide-generating system, primarily NADPH dependent, is however demonstrated in rabbit aorta adventitial fibroblasts [23], in mouse thoracic aorta vascular smooth muscle cells [84] and in cultured rat aortic smooth muscle cells [35]. The preferred substrate for oxidases in macrophages and neutrophils is also NADPH rather than NADH [35]. A similar NADH- and NADPH-dependent activity is found in human skin fibroblasts [85], neonatal rat cardiac myocytes [86] and in human embryonic kidney cells [87], while in rat liver plasma membranes the activity with $\mathrm{NADPH}$ is approximately $80 \%$ that of NADH [88]. The substrate preference of the superoxide-generating oxidase is thus highly cell type dependent with specificity to NADH oxidase in adult rat cardiac fibroblasts. Since NAD $(\mathrm{P}) \mathrm{H}$ does not cross plasma membranes their consumption rates measured in the extracellular medium are likely to represent oxidation by $\mathrm{NAD}(\mathrm{P}) \mathrm{H}$ oxidase on the outer aspect of the membrane.

The activation of NAD(P)H oxidase by ANG II in adult rat cardiac fibroblasts leads to a resultant increase in superoxide anion production, assessed as SOD-inhibitable cyto- 


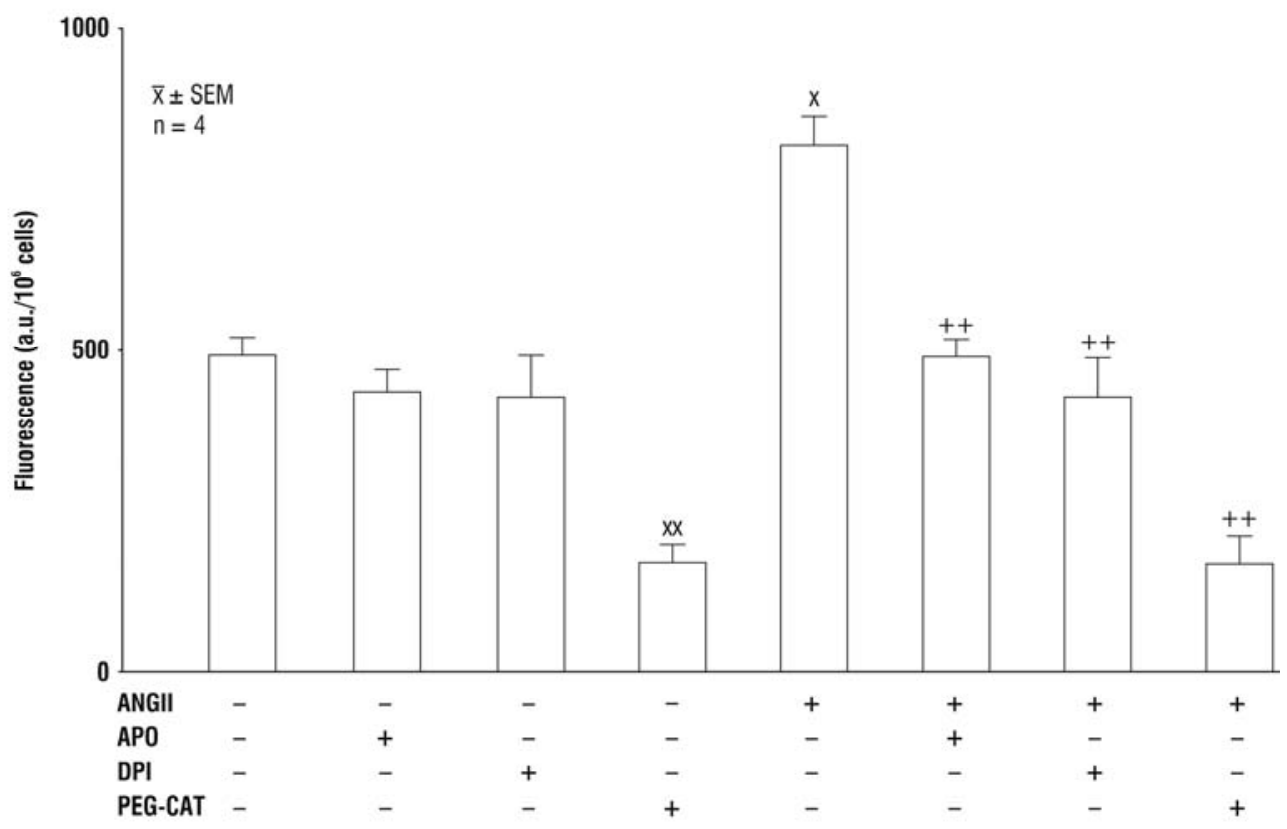

Fig. (4). Intracellular reactive oxygen species (ROS) generation, assessed in cardiac fibroblasts treated with(out) ANG II (1 $\mu$ mol/l) for 24 hours after preincubation with apocynin (APO, $100 \mu \mathrm{mol} / \mathrm{l}$ ), diphenyleneiodonium chloride (DPI, $2 \mu$ mol/l) or polyethylene glycol-catalase (PEG-CAT, 350 Units $/ \mathrm{ml}$ ) for $1 \mathrm{~h}$, and incubated with 2',7'-dichlorofluorescein diacetate $(20 \mu \mathrm{mol} / \mathrm{l})$ for $30 \mathrm{~min} . \mathrm{xx} \mathrm{p}<0.01$, $\mathrm{x} \mathrm{p}<0.05$ compared with control without ANG II and APO, DPI and PEGCAT; ++ p<0.01 compared with samples with ANG II and without APO, DPI and PEG-CAT.

chrome c reduction [67]. The intracellular generation of ROS such as hydrogen peroxide, hydroxyl radical and hydroperoxides, assessed with the fluorescent probe 2,7 -dichlorofluorescein diacetate, is also increased by ANG II in adult $[67,79]$ and neonatal $[89,90]$ rat cardiac fibroblasts. This increase is completely blocked by DPI, apocynin and polyethyleneglycol-catalase (Fig. 4).

These data indicate that ANG II increases oxidative stress and $\mathrm{NAD}(\mathrm{P}) \mathrm{H}$ oxidase activity in adult rat cardiac fibroblasts and that the enhanced generation of ROS is blocked by inhibition of the NAD(P)H oxidase complex with apocynin or DPI.

ANG II activates NAD(P)H oxidase to generate ROS via the angiotensin subtype 1 receptor and those ROS are, at least partly, involved in the activation of ERK, JNK and p38MAPK pathways in cardiac fibroblasts [89]. p38 MAPK activated protein kinase is indeed a critical component of the redox-sensitive signaling pathway activated by ANG II [91]. However, ERK1/2 and JNKs, but not p38kinase, are involved in ROS-mediated induction of osteopontin gene expression by angiotensin II in adult rat cardiac fibroblasts [92]. Osteopontin, expressed in the myocard co-incident with heart failure, plays an important role in post myocardial infarction remodeling by promoting collagen synthesis and accumulation.

ANG II also activates the transcription factors AP-1 and $\mathrm{NF}-\mathrm{\kappa B}$, the best characterized transcription factors to be influenced by the cellular redox state [89, 93]. In addition to influencing tyrosine kinases, protein phosphatases and MAPkinases, ROS modulate intracellular $\mathrm{Ca}^{2+}$ signaling in endothelial and vascular smooth muscle cells [68]. ROS increase intracellular $\mathrm{Ca}^{2+}$ by stimulating inositol $1,4,5-$ triphosphate-mediated mobilization of intracellular $\mathrm{Ca}^{2+}$, by increasing cytosolic $\mathrm{Ca}^{2+}$ accumulation through inhibition of sarcoplasmic/endoplasmic reticulum $\mathrm{Ca}^{2+}$-ATPase and by stimulating $\mathrm{Ca}^{2+:}$ influx through voltage-dependent $\mathrm{Ca}^{2+}-$ channels in these cells [91]. ROS also influence contractile processes by stimulating Rho/Rho kinase cascades [94].

In cardiac fibroblasts the reduction in intracellular calcium levels results also in enhanced endogenous superoxide anion production, which underscores a possible link between extracellular calcium and superoxide anion production [95]. In hypomagnesemia, serum factors may stimulate cardiac fibroblast proliferation via a superoxide anion-mediated mechanism and contribute to the fibrogenic response in the heart, even when cardiac tissue levels of magnesium are well preserved [96]. The exact mechanism, either direct or indirect, by which ANG II affects ROS in rat cardiac fibroblasts and especially the NOX-subunit of the $\mathrm{NAD}(\mathrm{P}) \mathrm{H}$ oxidase complex involved in the production of ROS need, however, to be further elucidated. In human cardiac fibroblasts Cucoranu et al. [97] provided recently compelling evidence that Nox-4 and Nox-5 are the primary Nox subunits.

In rat aortic smooth muscle cells Nox4 is responsible for the basal production of $\mathrm{H}_{2} \mathrm{O}_{2}$, while Nox1 is required for ANG II-stimulated $\mathrm{O}_{2}{ }^{-}$production [98].

\section{ANG II-INDUCED EFFECT ON SUPEROXIDE DISMUTASE ACTIVITY IN CARDIAC FIBRO- BLASTS}

ANG- II decreases total SOD, CuZn-SOD and Mn-SOD activity in rat cardiac fibroblasts [99]. No EC-SOD activity 
was however detectable in adult rat cardiac fibroblasts [99]. Marklund [100] reported that the CuZn-SOD content in the rat heart was much higher than the Mn-SOD content (on average 15,100 versus 2,125 Units/g wet weight), whereas the EC-SOD content was very low (35 U/ g wet weight). In ANG II-treated rats an increased mRNA expression of MnSOD, $\mathrm{p} 22^{\text {phox }}$ and Nox 1 and a decreased mRNA level of ECSOD and Nox4 is found in the kidney cortex compared to controls [101]. ANG II infusion in mice also reduces the total SOD activity in plasma, aorta and kidney cortex as well as the mRNA and protein expression for EC-SOD [102]. Compared to the normal rat heart, gp $91^{\text {phox }}$ mRNA is largely increased within the perivascular and microscopic injury in both ventricles in ANG II-treated rats and cells expressing gp91 ${ }^{\text {phox }}$ at these sites were primarily inflammatory cells; cardiac Mn-SOD and catalase protein levels, however, remain unchanged in ANG II-infused rats [103]. In ANG IIinfused mice the aorta mRNA and protein expression of ECSOD as well as the EC-SOD activity is increased, while the $\mathrm{CuZn-SOD}$ protein expression is unchanged [104]. ANG II also increases aortic EC-SOD protein expression in mouse organoid cultures and enhances the mRNA EC-SOD level in cultured human aortic smooth muscle cells [104]. EC-SOD activity in mouse aorta and in human aortic smooth muscle cells is also strongly induced by ANG II [105]. Incubation of mouse aortic homogenates with ANG II had no effect on total SOD activity in either wild type or CuZn-SOD deficient mice [106]. Taking these in vitro and in vivo data together indicate that the effect of ANG II on SOD is highly cell specific.

\section{DOWN-REGULATION OF MN-SOD BY ANGIO- TENSIN II IN CARDIAC FIBROBLASTS}

In cultured rat cardiac fibroblasts ANG II decreases the mRNA and protein expression of the mitochondria-specific antioxidant Mn-SOD (Fig. 5), but without influencing $\mathrm{Cu}$, $\mathrm{Zn}-\mathrm{SOD}$, catalase or glutathioneperoxidase mRNA and protein expression [107].
Discordant findings are reported on the in vivo effect of ANG II on Mn-SOD activity, protein and mRNA expression in various animal tissues. In ANG II-infused rat kidney a $50 \%$ decrease in Mn-SOD activity is observed [108], while Chabrashvili et al. [101] reported an increased mRNA expression of Mn-SOD in the kidney cortex of ANG IItreated rats. An unchanged $\mathrm{Mn}-\mathrm{SOD}$ protein expression is found in cardiac [103] and kidney [108] tissue of ANG IIinfused rats, while a reduced renal Mn-SOD protein level is found in ANG II-treated rats [109]. In ANG II-infused mice, the aortic protein level Mn-SOD is unchanged, but declines in extracellular SOD deficient mice [110]. In Dahl saltsensitive rats, characterized by an up-regulated angiotensin system [111], renal Mn-SOD protein expression is decreased and increased by the angiotensin converting enzyme inhibitor, trandolapril [112]. In spontaneously hypertensive rat (SHR) kidneys, chronic ANG II-blockade with losartan prevents the decrease in Mn-SOD activity and the increase in $\mathrm{H}_{2} \mathrm{O}_{2}$ production observed in untreated SHR [113]. Losartan also inhibits the ANG II-induced Mn-SOD mRNA downregulation in cardiac fibroblasts [107]. A reduced Mn-SOD gene and protein expression is also observed in the infarcted myocard of rats $[114,115]$ and this fall is partially prevented by losartan [115]. The diminished Mn-SOD mRNA levels are not related to changes in Mn-SOD mRNA stability. The down-regulation of Mn-SOD is linked to a down-regulation of its mRNA levels, thus indicating that the alterations in Mn-SOD expression result from an altered gene expression rather than from alterations in post-transcriptional regulation. Moreover, the protein expression of $\alpha$-smooth muscle actin, a marker of the differentiation of fibroblasts into myofibroblasts, is not affected by ANG II, indicating that the effects of ANG II on Mn-SOD expression do not result from changes in the phenotype of the cultured fibroblasts [107].

\section{MITOCHONDRIAL ROS PRODUCTION AND ANGIOTENSIN II IN CARDIAC FIBROBLASTS}

In quiescent cells most of ROS are produced through an univalent reduction of molecular oxygen to $\mathrm{O}_{2}{ }^{-}$by electrons

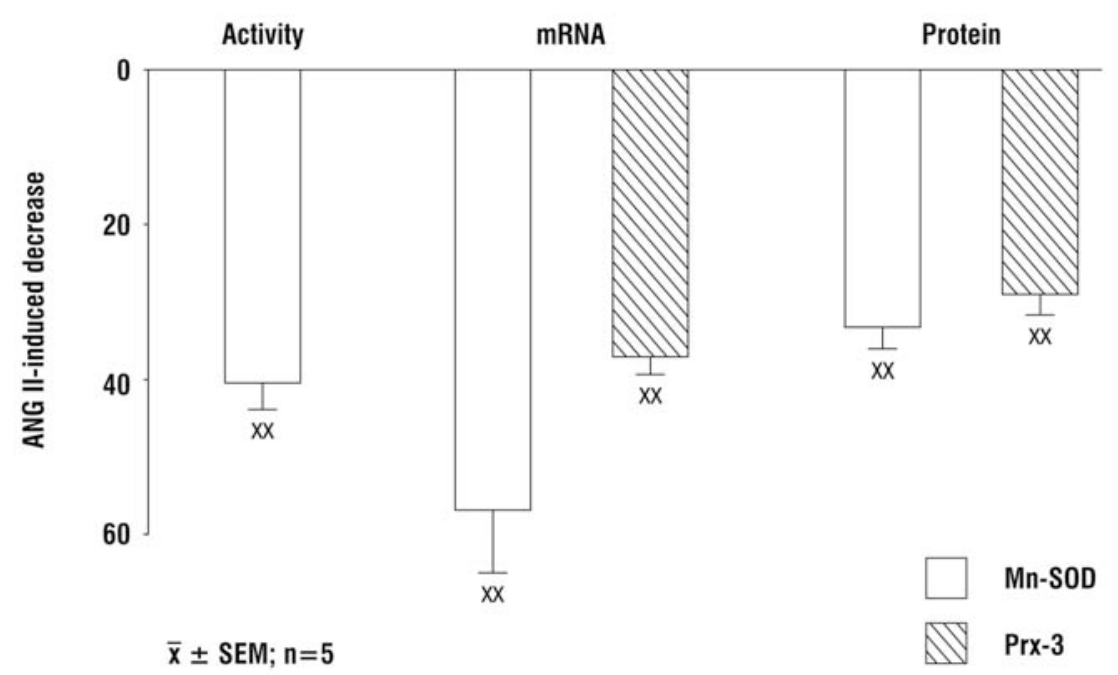

Fig. (5). ANG II-induced decrease in activity, mRNA and protein expression of manganese superoxide dismutase (Mn-SOD) and peroxiredoxin-3 (Prx-3) in cardiac fibroblasts treated with(out) ANG II $(1 \mu \mathrm{mol} / 1)$ for 24 hours. $\mathrm{xx} p<0.01$, $\mathrm{x}<<0.05$ compared to control. 


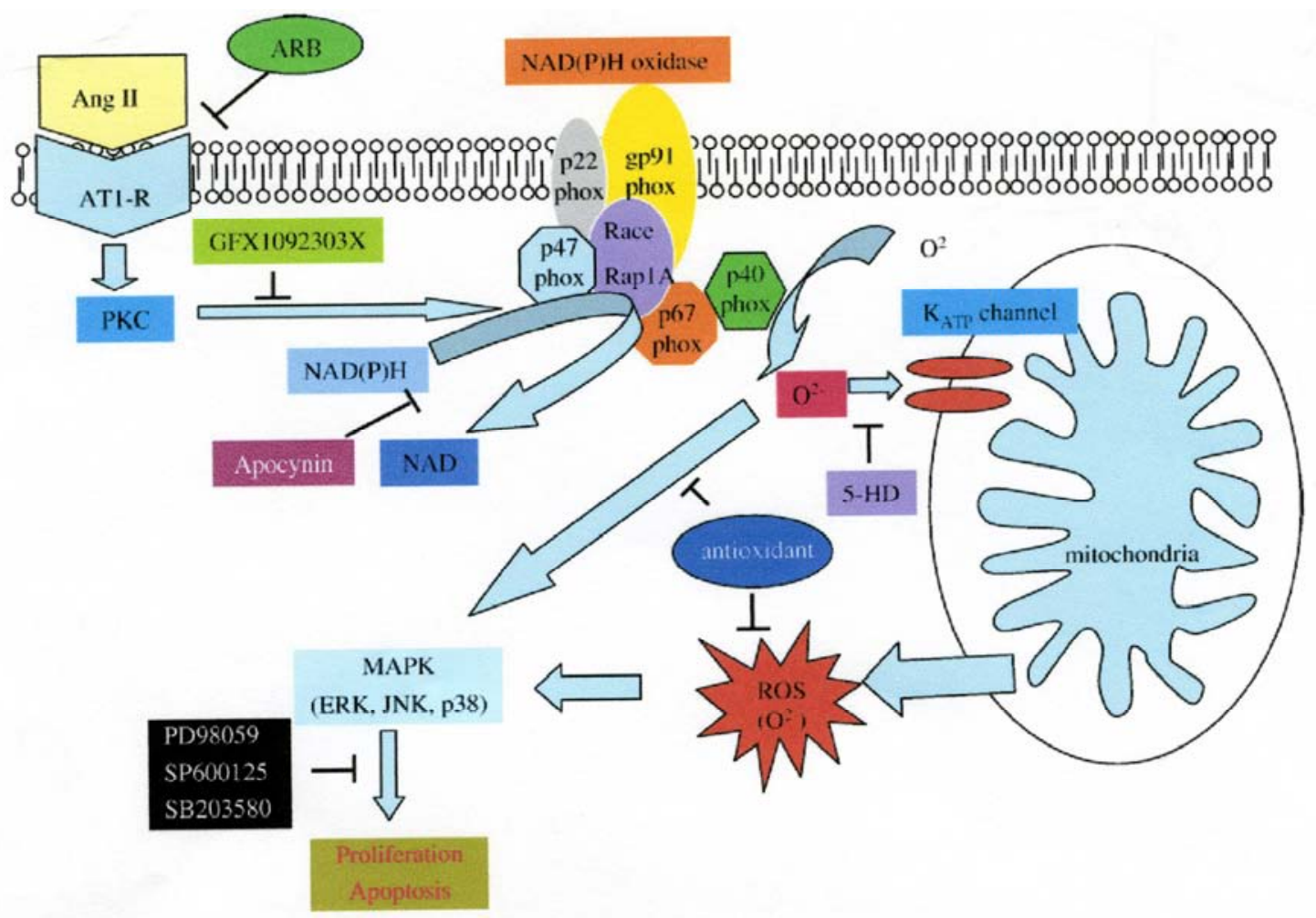

Fig. (6). Potential signaling pathways in ANG II-stimulation. ARB Angiotensin II receptor blocker, AT1-R angiotensin II subtype 1 receptor; PKC protein kinase C; PKC inhibitor (GFX1092303X), NADPH oxidase inhibitor (apocynin), Mitochondrial $\mathrm{K}_{\mathrm{ATP}}$ channel inhibitor (5hydroxydecanoate, 5-HD), ERK inhibitor (PD98059), JNK inhibitor (SP600125), p38 inhibitor (SB203580). Reprinted from [120] with permission from Oxford University Press, Oxford, U.K.

that leak from complex I and III of the mitochondrial electron transport chain. The mitochondrial electron transport system consumes approximately $85 \%$ of the oxygen utilized by cells, and about $5 \%$ of that oxygen is converted to ROS $[116,117]$. The burden of ${ }^{\circ}{ }_{2}^{-}$is largely countered by the mitochondrial enzyme Mn-SOD. Although Mn-SOD relieves oxidative stress in mitochondria caused by $\mathrm{O}_{2}{ }^{-}$, it generates $\mathrm{H}_{2} \mathrm{O}_{2}$ a mild oxidant which is readily converted to the more powerful oxidant $\mathrm{OH}$.

Chronic increases in mitochondrial ROS production can lead to a catastrophic cycle of further oxidative stress and ultimate cellular injury [118]. This deleterious process may play an important role in the development and progression of myocardial remodeling and failure [119]. Indeed, recent findings [120] have demonstrated that ANG II stimulation induces opening of mitochondrial $\mathrm{K}_{\mathrm{ATP}}$ channels and further amplifies ROS formation from mitochondria. ROS produced initially in the mitochondria have been shown to act in a positive feedback, where mitochondria can respond to elevated ROS by increasing their own ROS production in a process known as ROS-induced ROS release [121]. ANG II stimulation activates NADPH oxidase to generate ROS which activates mito $\mathrm{K}_{\text {ATP }}$ channels to induce a ROS burst in the mitochondria to activate downstream signaling pathways, such as activation of p38 and JNK MAPK involved in cell apoptosis, hypertrophy and differentiation [120]. ANG II binds to ANG type 1 receptors $\left(\mathrm{AT}_{1}-\mathrm{R}\right)$, activates protein kinase $\mathrm{C}(\mathrm{PKC})$ which activates NADPH oxidase to induce $\mathrm{O}_{2}-$ generation (Fig. 6). Mitochondrial $\mathrm{K}_{\mathrm{ATP}}$ channels can be activated by $\mathrm{O}_{2}{ }^{-}$to produce more generation of ROS to induce activation of MAPK, which mediates ANG IIinduced cell proliferation, apoptosis and differentiation [120].

Exposure of cardiac fibroblasts to ANG II can thus lead to increased oxidative stress because of down-regulation of antioxidant enzymes such as manganese superoxide dismutase. The Mn-SOD mimetic tempol [122] on the contrary completely abolishes the ANG II-induced increase in $\mathrm{O}_{2}$ production in cardiac fibroblasts [67].

It has indeed been shown that lack of Mn-SOD in mice results in dilated cardiomyopathy [123], induces progressive heart failure with excess formation of superoxide and transcriptional alterations of genes associated with heart failure [124] and leads to severe impaired vasorelaxation, high levels of mitochondrial ROS formation and mitochondrial DNA damage [125]. Decreased Mn-SOD activity promotes also atherosclerotic lesion development and increases aortic mtDNA damage in apoE ${ }^{-/-}$mice $[126,127]$. Miller et al. [128] reported that chronic increases in oxidative stress, produced by mitochondrial Mn-SOD deficiency in mice, impair vascular function via a $\mathrm{H}_{2} \mathrm{O}_{2}$-dependent, cyclooxygenase 1-dependent endothelium-derived contracting factor.

On the contrary, mice over-expressing Mn-SOD has reduced infarct size compared to wild type [129] and diminished severity of diabetic cardiomyopathy [130]. In rats, over-expression of $\mathrm{Mn}$-SOD in carotid arteries results in reduced $\mathrm{O}_{2}{ }^{-}$production in response to endothelin-1 [131] and in the rostral ventrolateral medulla it attenuates the ANG IIinduced pressor response and suppressed ANG II-induced 
ROS production [132]. Transgenic mice with increased MnSOD expression in the liver have $23 \%$ fewer bromodeoxyuridine-positive cells and a marked attenuation of proliferative cell nuclear antigen expression, leading to delayed entry into S phase [133]. The increase in Mn-SOD activity also leads to an increase in the mitochondrial thioredoxin-2, but not in other peroxidases, suggesting the importance of thioredoxin-2 in maintaining redox balance in mitochondria with elevated levels of Mn-SOD [133]. Studies with fibroblasts have shown that increased Mn-SOD expression prolongs cell type transition time in $\mathrm{G}_{1} / \mathrm{S}$ and favors entrance into the quiescent state $[134,135]$.

Mitochondrial oxidative stress and damage seems also to play a major role in the development and progression of left ventricular remodeling and failure after myocardial infarction [136, 137]. In the failing ventricular myocard from patients with end-stage heart failure a marked decline in mitochondrial Mn-SOD protein and activity is detected [138]. Mitochondrial biogenesis is also severely impaired as evidenced by reduced mtDNA replication and depletion of mtDNA in the human failing heart [139].

Both acute (24 hours) and chronic (14 days) ANG II treatment in mice results also in decreased expression of mitochondrial metabolic genes, notably those for the electron transport chain and Krebs-TCA cycle [140]. Chronic ANG II treatment also results in decreased expression of genes involved in fatty acid metabolism [140]. In contrast, genes involved in protein translation and ribosomal activity increase expression following both acute and chronic ANG II administration [140]. It has also been demonstrated by Kienhöfer et al. [141] that mtDNA is associated with an antioxidant system in mammalian cells with Mn-SOD binding directly to mtDNA. Mn-SOD is thus essential to protect mitochondrial genome from oxidative damage.

\section{DOWN-REGULATION OF PEROXIREDOXIN-3 EXPRESSION BY ANGIOTENSIN II IN CARDIAC FIBROBLASTS}

Cardiac fibroblasts are protected from oxidative stress, triggered by inflammation after myocardial injury or induced by ANG II or growth factors, by expressing potent antioxidant defenses such as superoxide dismutases, catalases, glutathione peroxidases and peroxiredoxins [142, 143].

Multiple peroxiredoxins or thioredoxin peroxidases, (Prx-1 through -6) are identified in mammalian cells in different intracellular locations and protect cells and tissues from damage caused by ROS [144-147]. All six peroxiredoxins are present in cardiac fibroblasts. Prx-1, -2 and -6 are localized in the cytosol, Prx-3 in mitochondria, Prx-4 in the extracellular space and Prx-5 is localized intracellularly to cytosol, mitochondria and peroxisomes [148, 149]. Prx-3 is found exclusively in the mitochondria [143] and uses mitochondrial thioredoxin (Trx-2) as the electron donor for its peroxidase activity [150]. Prx-3 functions not only by removing $\mathrm{H}_{2} \mathrm{O}_{2}$ formed after the SOD-catalysed dismutation but also by detoxifying peroxynitrite [151].

ANG II decreases the mRNA and protein expression of the mitochondrial specific antioxidant Prx-3 (Fig. 5), while the cytosolic Prx-1 fraction is unaffected [152].
A down-regulation of Prx-3 has been described in various experimental models that are characterized by an increased cellular oxidative stress [153-155]. In human heart failure Brixius et al. [156] have also reported a selective down-regulation of the mitochondrial Prx-3 and Prx-5 as well as that of the extracellular Prx-4 isoform and that of the cytosolic Prx-6, while the cytosolic Prx-1 and Prx-2 isoforms are unaffected by the enhanced ROS production.

Thus reducing Prx-3 sensitizes cells to oxidative stress [157]. Furthermore, Prx-3 knockdown by siRNA increases mitochondrial ROS [158] and Prx-3 knock-out mice are more susceptible to lipopolysaccharide-induced oxidative stress than their wild-type littermates [159]. Higher levels of ROS are detectable in macrophages derived from these mice and they release increased amounts of TNF $\alpha$ [160]. Taken all data together suggest that the loss of Prx-3 results in increased susceptibility to oxidative stress. Thus, it may be concluded that an increase in cellular oxidative stress seems also to be paralleled by a down-regulation of mitochondrial Prx-3.

Chronic increases in mitochondrial ROS production can lead to a catastrophic cycle of further oxidative stress and ultimate cellular injury [161]. This deleterious process may play an important role in the development and progression of myocardial remodeling and failure [162].

Given that mitochondria contain Prx-3 30 times more abundant than glutathione peroxidase and that they lack catalase [157], Prx-3 is thought to be a primary line of defense against $\mathrm{H}_{2} \mathrm{O}_{2}$ produced by the mitochondrial respiratory chain, as Mn-SOD does against $\mathrm{O}_{2}{ }^{-}$.

The specific localization of Prx-3 in the mitochondria suggests that mitochondrial oxidative stress plays an important role in the development and progression of heart failure and the antioxidant localized specifically within the mitochondria provides a primary line of defense against the disease process [143].

Indeed, over-expression of Prx-3 protects the heart against post-MI remodeling and failure in mice [161]. It reduces LV cavity dilatation and dysfunction as well as myocyte hypertrophy, interstitial fibrosis and apoptosis of the non-infarcted myocard. These beneficial effects of Prx-3 gene over-expression are associated with the attenuation in oxidative stress, mtDNA decline and dysfunction [163]. Prx3 over-expression has also been shown to improve glucose homeostasis, with transgenic mice displaying resistance to diet-induced elevations in blood glucose and increased glucose clearance [164].

Prx-3 is thus an important candidate for therapy against LV failure after MI, in which ROS production has been found to be increased within the mitochondria [161]. Recently it has been shown that an elevated cytosolic $\mathrm{Na}^{+}$ increases mitochondrial formation of ROS in failing cardiac myocytes of guinea pigs [165].

\section{REGULATION OF MN-SOD EXPRESSION BY FOXO3A IN CARDIAC FIBROBLASTS}

In human cardiac fibroblasts the Forkhead box class o transcription factor FOXO3a mediates the expression of 
peroxiredoxin-3, which functions to protect mitochondria against oxidative stress by scavenging $\mathrm{H}_{2} \mathrm{O}_{2}$ [166].

FOXO transcription factors may be important in the regulation of the antioxidant defense in many species [163]. It has indeed been shown that FOXO3a interacted with the promoter of the rat Mn-SOD gene at a specific binding site, located $1272 \mathrm{bp}$ upstream of the coding region of the rat MnSOD promoter [167]. In rat cardiac fibroblasts ANG II also reduces the binding of FOXO3a to the Mn-SOD promoter [107]. Inhibition of FOXO3a transcription with small interfering RNA leads to a reduced FOXO3a binding to the Mn-SOD promoter and a concomitant reduction in Mn-SOD gene expression in control cardiac fibroblast [107], implying that FOXO3a does up-regulate Mn-SOD. Specific activation of FOXO3a by 4-hydroxy-tamoxifen, a modified ligand of the estrogen receptor, increases Mn-SOD mRNA expression in control fibroblasts and reverses the ANG II-induced reduction in Mn-SOD gene expression [107]. In FOXO3a depleted fibroblasts the reduced Mn-SOD expression is also associated with an increased $\mathrm{O}_{2}$ - production [105]. Our data suggest thus that FOXO3a may be the transcription factor responsible for the ANG II-induced down-regulation of MnSOD in cardiac fibroblasts. ANG II-stimulated Akt (protein kinase B) activity might thus responsible for the phosphorrylation and inactivation of FOXO3a which in turn downregulates $\mathrm{Mn}$-SOD transcription in adult rat cardiac fibroblasts. In DL23 cells FOXO3a also increases the expression of Mn-SOD [167] and a lower Mn-SOD protein and activity in vascular smooth muscle cells from old rats is also paralleled by a reduction in $\mathrm{FOXO}$ a transcriptional activity [168]. Although FOXO3a is able to regulate mRNA and protein levels of catalase in neonatal rat cardiomyocytes [168], no changes in activity, mRNA and protein expression of catalase are found in adult rat cardiac fibroblasts [107]. This has to be further elucidated in various cardiac cell types of neonatal and adult rat hearts. It should however taken into account that catalase has been detected in mitochondria from rat heart $[169,170]$, but this is at low nanomolar concentrations $(0.025 \%$ of rat heart mitochondrial protein) and therefore probably not regarded to play a significant role in mitochondrial ROS detoxification in rat heart mitochondria [171].

ANG II is thus linked with increased Akt phosphorrylation in cardiac fibroblasts and consequent reduction in FOXO3a transcriptional activity leading to downregulation of Mn-SOD gene expression. Upon phosphorylation of Akt by ANG II P-Akt is indeed translocated from the cytoplasm to the nucleus and nuclear phosphorylation of FOXO3a by P-Akt leads to relocalization of FOXO3a from the nucleus to the cytosol [107], thus resulting in a decrease in its transcriptional activity and in Mn-SOD expression. Inhibition of PI3K with wortmannin and LY294002 and Akt inhibition leads to a decrease in P-Akt, to an increased Mn-SOD mRNA expression and a reduced $\mathrm{O}_{2}^{-}$production [107]. This shuttling mechanism contributes to the down-regulation of Mn-SOD gene expression. In adult rat cardiac fibroblasts ANG II also provides protection against NO-stimulated apoptosis by activating a PI3kinase-Akt-mediated survival signaling pathway [172]. ANG II inactivates thus FOXO3a by activating Akt and this leads to a reduction in the expression of the antioxidant Mn-SOD contributing to the ANG II-induced ROS production. ANG II may thus cause an increased oxidative stress by inhibiting the expression and activity of the mitochondrial enzyme Mn-SOD engaged in ROS breakdown.

\section{ANG II-INDUCED OXIDATIVE STRESS AND MODULATORY EFFECT OF DETC}

The irreversible CuZn-SOD inhibitor DETC increases, while the $\mathrm{O}_{2}{ }^{-}$scavenging agent tempol inhibits completely,

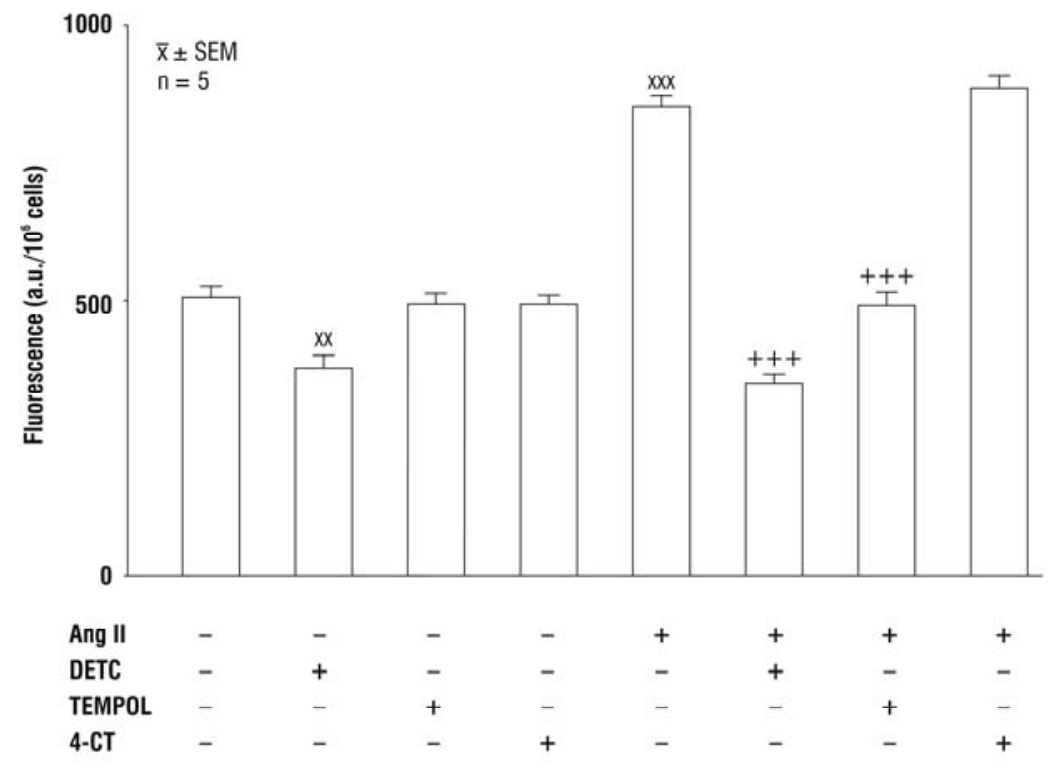

Fig. (7). Intracellular reactive oxygen species (ROS) generation, assessed in cardiac fibroblasts treated with(out) ANG II (1 $\mu$ mol/l) for 24 hours after preincubation with diethyldithiocarbamic acid (DETC, $100 \mu \mathrm{mol} / \mathrm{l})$, tempol or 4-carboxy-tempol $(4-\mathrm{CT}, 1 \mu \mathrm{mol} / \mathrm{l})$ for $1 \mathrm{~h}$, and incubated with 2',7'-dichlorofluorescein diacetate $(20 \mu \mathrm{mol} / \mathrm{l})$ for $30 \mathrm{~min}$. $\mathrm{xxx} \mathrm{p}<0.001$, xx $\mathrm{p}<0.01$ compared with control without ANG II and DETC, tempol and 4-CT; +++ p<0.001 compared with samples with ANG Ii and without DETC, tempol and 4-CT. 
the $\mathrm{O}_{2}{ }^{-}$production in control and ANG II-treated adult rat cardiac fibroblasts (Fig. 7) [97].

An enhanced $\mathrm{O}_{2}{ }^{-}$generation by DETC in rats has been reported in various cell types such as neonatal cardiac fibroblasts [24] and myocytes [12], aortic rings [22,173], renal medullary tissue [174], vascular smooth muscle cells [26], aortic adventitial fibroblasts [175] and intact middle cerebral and basilar arteries [176]. DETC also causes a dosedependent increase in levels of $\mathrm{O}_{2}{ }^{-}$in rings of rabbit aorta [23]. Besides an increase in $\mathrm{O}_{2}^{-}$production in cardiac fibroblasts DETC also reduces the intracellular ROS production in control and ANG II-treated cardiac fibroblasts [97]. Colston et al. [177] also reported a decreased ROS production by DETC in adult rat cardiac fibroblasts, while in adult rat cardiac myocytes an increased ROS generation is found [178]. These data indicate that in adult rat cardiac fibroblasts oxidative stress is increased by ANG II, partially through down-regulation of antioxidant enzymes as SOD, and that DETC enhances $\mathrm{O}_{2}^{-}$production and decreased intracellular ROS formation as a consequence of inhibition of CuZn-SOD.

\section{ANG II-INDUCED COLLAGEN PRODUCTION AND DEGRADATION DURING INHIBITION OF CARDIAC FIBROBLAST SUPEROXIDE DISMU- TASE}

Inhibition of SOD by DETC and the subsequently increased $\mathrm{O}_{2}^{-}$production induces an increase in collagen production and fibronectin level in adult cardiac fibroblasts, while inhibition of $\mathrm{O}_{2}^{-}$generation by the SOD mimetics tempol and EUK-8 lowers the collagen production and fibronectin content (Fig. 8) [95].

The antioxidant tempol is a cell permeant scavenger of superoxide anion. In diabetic rats tempol administration also inhibits the mesangial expression of fibronectin and matrix expansion [179]. The increased cardiac collagen content as well as the collagen type I mRNA expression in chronic isoproterenol infused rats is reversed by tempol treatment [180]. In mice subjected to pressure overload, EUK-8 also atenuates cardiac hypertrophy and fibrosis, prevents myocardial oxidant stress and improves LV end-systolic dimensions and fractional shortening [181].

In neonatal rat cardiac fibroblasts however DETC inhibits collagen synthesis and increased total MMP activity [24], while in neonatal cardiac myocytes DETC reduces cardiac hypertrophy through a ROS-dependent mechanism [12].

Administration of PEG-SOD to cardiac fibroblasts induces however a decrease in collagen deposition [95]. In pig skin fibroblasts in a three-dimensional model, SOD administered as liposod CuZn-SOD also significantly lowers the level of the extracellular matrix components $\alpha_{1}(\mathrm{I})$ collagen and tenascin- $\mathrm{C}$ and of the myofibroblast marker $\alpha$ smooth muscle actin [26]. In ANG II-induced hypertension in rats, both hypertension and the impairment of vasodilator responses to acetylcholine and calcium ionophores are improved by treatment with liposome-encapsulated SOD [15], In ANG II-treated rats liposome-entrapped SOD increases total SOD activity by $30 \%$ in vascular homogenates, normalizes vascular $\mathrm{O}_{2}^{-}$production and reduces blood

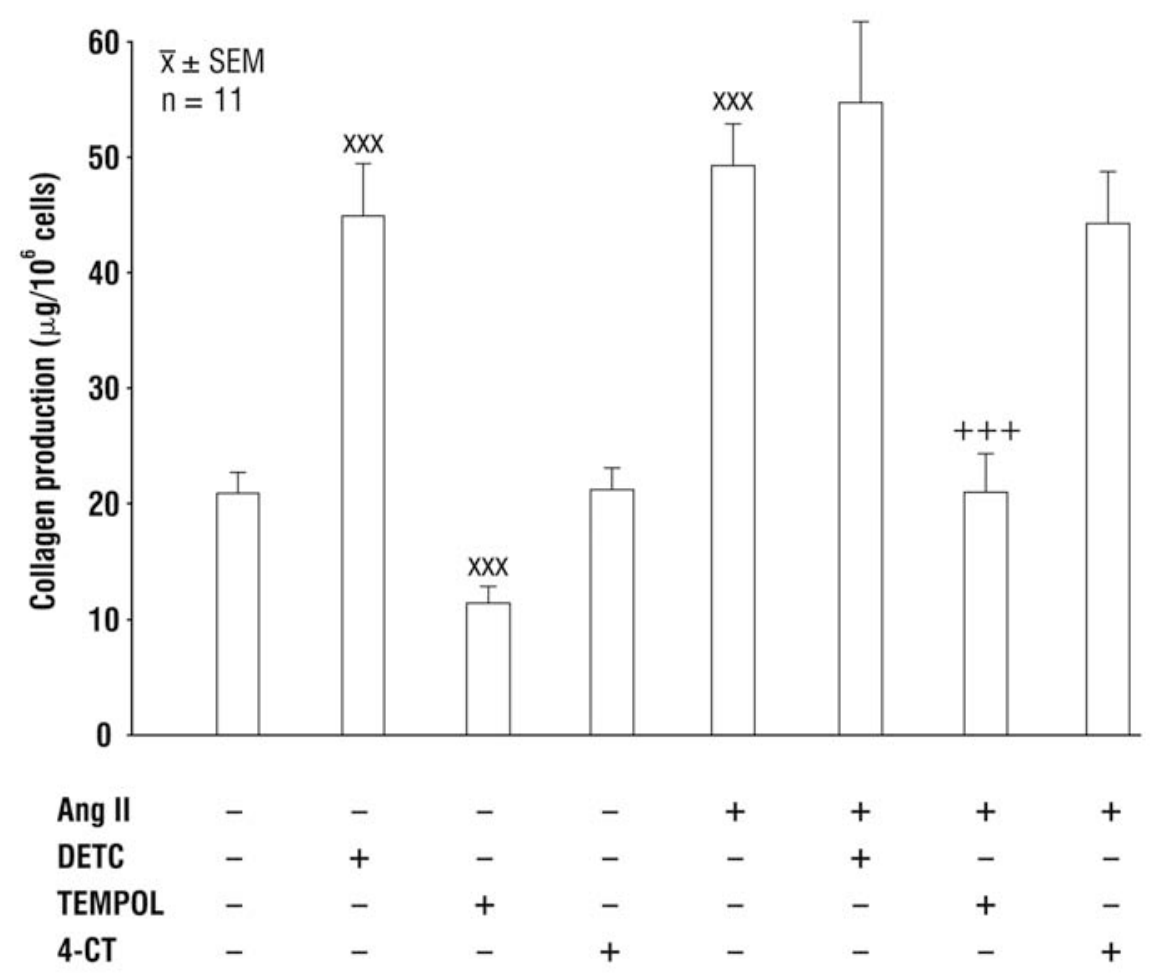

Fig. (8). Soluble collagen production in cardiac fibroblasts treated with(out) ANG II $(1 \mu \mathrm{mol} / \mathrm{l})$ for 24 hours after preincubation with diethyldithiocarbamic acid (DETC, $100 \mu \mathrm{mol} / \mathrm{l})$, tempol or 4-carboxy-tempol (4-CT, $1 \mu \mathrm{mol} / \mathrm{l})$ for $1 \mathrm{~h}$. $\mathrm{xxx}$ p<0.001 compared with control without ANG II and DETC, tempol and 4-CT; +++ p<0.001 compared with samples with ANG II and without DETC, tempol and 4-CT. 

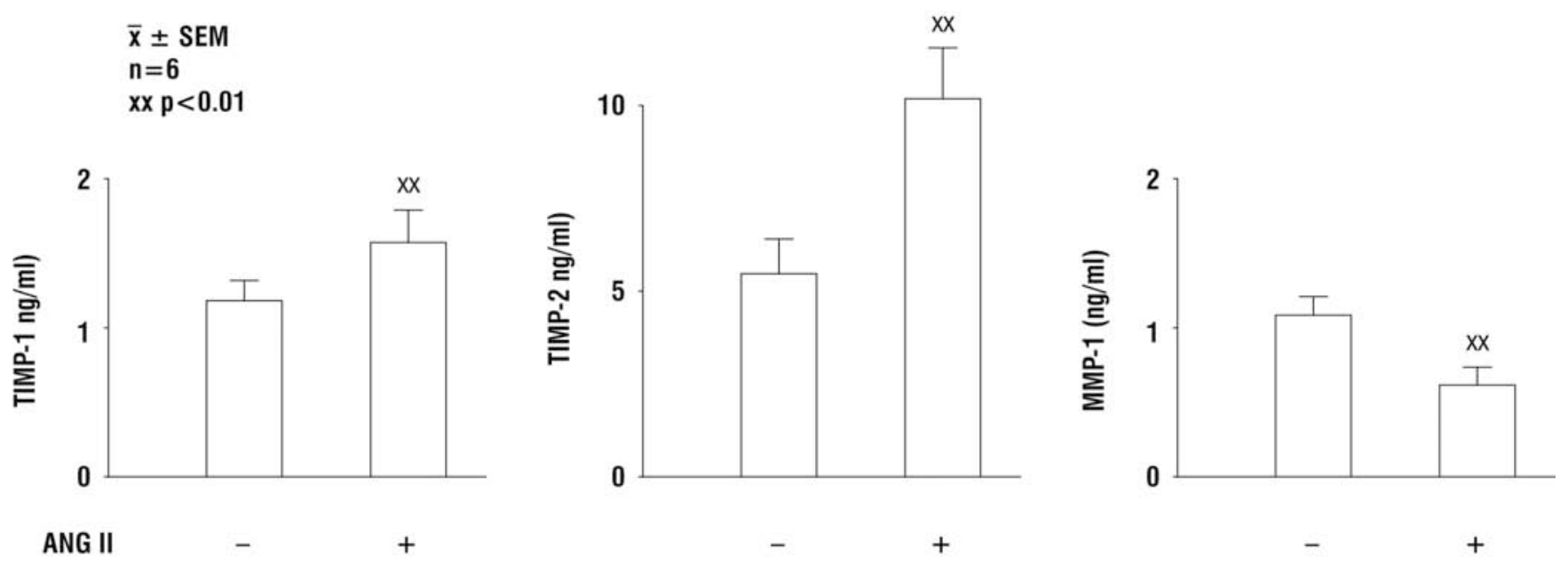

Fig. (9). TIMP-1, TIMP-2 and MMP-1 level in the medium of cardiac fibroblasts treated with(out) ANG II (1 $\mu$ mol/l) for 24 hours. xx $\mathrm{p}<0.01$ compared to control (-).

pressure [182]. In vivo administration of lecithinized SOD in rats inhibits oxidative stress and improves outcomes after focal cerebral ischemia [183]. An inhibitory effect of phosphatidylcholine-SOD on bleomycin-induced pulmonary fibrosis in mice is also reported [184]. SOD is indeed already successfully used as an antifibrotic agent in the treatment of cutaneous fibrosis both in clinical trials [185, 186] as in animal experimental studies [187].

The stimulation of the collagen production by SOD inhibition with DETC and the inhibition of the collagen production by PEG-SOD and by the SOD mimetics tempol and EUK-8 [95] suggest a vital role of SOD and the formed ROS in the regulation and organization of collagen in cardiac fibroblasts. Indeed, over-expression of SOD in mouse aortic adventitial fibroblasts inhibits the ANG IIinduced type I procollagen $\alpha$-I protein expression and $\mathrm{O}_{2}{ }^{-}$ generation [188].

In adult rat cardiac fibroblasts DETC and ANG II stimulate collagen production and TIMP-1 and TIMP-2 synthesis [97] which inhibits collagen degradation by MMPs and leads to collagen accumulation. Indeed, ANG II decreases MMP-1 activity in adult rat cardiac fibroblasts [42,67,79] and increases TIMP-1 and TIMP-2 levels (Fig. 9) [97], with a more pronounced effect on TIMP-2 than on TIMP-1, but no effect on MMP-2 and MMP-9 level.

It has indeed been shown that adenovirus-mediated overexpression of TIMP-2 but not of TIMP-1, TIMP-3 or TIMP4 in cardiac fibroblasts increases collagen synthesis [189]. In TNF $\alpha$-stimulated neonatal rat cardiac fibroblasts ANG II also increases TIMP-1 expression and decreases MMP-2 activity [70]. Bergman et al. [190] on the contrary reported that ANG II moderately increased MMP-2 secretion in neonatal rat cardiac fibroblasts.

Compared with left ventricle hypertrophy, MMP-2 but not MMP-9 activity level in LV myocardium is increased with congestive heart failure (CHF) and inhibited by the ANG II-receptor blocker telmisartan, while the mRNA expression of MMP-2, MMP-9, MMP-13, TIMP-1 and TIMP-2 was increased with CHF and blocked by telmisartan [191].
At first glance MMP-2 expression should result in a decreased level of cardiac interstitial collagen. However, significant increases in interstitial collagen volume fraction are noted in MMP-2 transgenic mice compared with agematched littermate controls [192]. Analysis of cardiac tissue from patients with idiopathic dilated cardiomyopathy also shows a large increase in gelatinase activity associated with increased total collagen content [193]. Similarly, Matsusaka et al. [194] reported increased cardiac collagen content in mice with intact levels of MMP-2 as opposed to MMP-2 knockout mice. In MMP-1 transgenic mice Kim et al. [195] showed that cardiac expression of MMP-1 produced a net loss of cardiac interstitial collagen coincidence with a marked deterioration of both systolic and diastolic function. However, it has also to be taken into account that the more collagen is degraded the more is synthesized [196]. Consequently, synthesis exceeds degradation and leads also to accumulation of collagen [196]. It has also demonstrated that under physiological relevant conditions interstitial collagen is not efficiently cleaved by MMP-2 [197, 198].

\section{CONCLUSIONS}

The ANG II-stimulated collagen production, collagen type I and III protein and mRNA expression as well as the ANG II-enhanced superoxide anion and intracellular ROS production in adult rat cardiac fibroblasts are completely blocked by the membrane-associated NAD $(\mathrm{P}) \mathrm{H}$ oxidase inhibitor apocynin. The ANG II-decreased MMP-1 activity and increased TIMP- activity are also reversed by apocynin. The collagen production in cardiac fibroblasts is however stimulated by SOD inhibition with DETC and inhibited by the SOD mimetics tempol and EUK- 8 and by PEG-SOD administration. These data suggest a role of SOD and the generated ROS in the myocardial accumulation of collagen.

\section{PERSPECTIVES}

Superoxide anion generated by $\mathrm{NAD}(\mathrm{P}) \mathrm{H}$-oxidase has an important role in the pathogenesis of cardiovascular diseases and scavenging superoxide anion can be considered as a reasonable therapeutic strategy $[199,200]$. In this review we 
demonstrate that scavenging superoxide anion by tempol or EUK-8 or administration of PEG-superoxide dismutase inhibits collagen production in cardiac fibroblasts. On the contrary increasing superoxide anion formation by inhibition of superoxide dismutase stimulates collagen production. A vital role of superoxide dismutase and the generated reactive oxygen species can be suggested in the myocardial collagen accumulation.

Specific pharmacological intervention with superoxide dismutase mimetics can probably be an alternative approach for reducing myocardial fibrosis.

A growing body of evidence suggests that oxidative stress, a chronic increase in reactive oxygen species (ROS), in the myocard can contribute to myocardial remodeling and failure. Furthermore, antioxidants have been shown to exert protective and beneficial effects against this process. Mitochondria are the predominant source of ROS and miotochondria antioxidants are expected to be the first line of defense against mitochondrial oxidative stress-mediated myocardial injury. Angiotensin II increases mitochondrial ROS production in cardiac fibroblasts and decreased the protein and mRNA expression of the mitochondrial antioxidant Mn-SOD by induction of the phosphorylation of Akt and FOXO3a and repression of the FOXO3a binding to the Mn-SOD promoter gene. Exposure to angiotensin II could thus lead to increased oxidative stress because of down-regulation of antioxidant enzymes such as Mn-SOD and Prx-3. These antioxidants are specifically localized in the mitochondria. It could thus provide a primary line of defense against angiotensin IIinduced oxidative stress and myocardial injury. Therapies designed to interfere with mitochondrial oxidative stress by using antioxidants such as SOD-mimetics might be beneficial in hypertensive heart diseases and in preventing heart failure.

\section{ACKNOWLEDGEMENTS}

The authors gratefully acknowledge the technical and secretarial assistance of Mrs. T. Coenen and Mrs. Y. Piccart.

\section{SOURCE OF FUNDING}

This work is supported by an educational grant from AstraZeneca (Belgium).

\section{DISCLOSURE}

Part of the information included in this article has been previously been published in Cardiovascular Therapeutics. This article is however an extended and updated version with nine additional figures on the stimulation of reactive oxygen species and collagen synthesis by angiotensin II in cardiac fibroblasts.

\section{REFERENCES}

[1] Mallat Z, Philip I, Lebret M, Chatel D, Maclouf J, Tedgui A. Elevated levels of 8-iso-prostaglandin $\mathrm{F}_{2 \alpha}$ in pericardial fluid of patients with heart failure: a potential role for in vivo oxidant stress in ventricular dilatation and progression to heart failure. Circulation 1998; 97: 1536-9.
[2] Dhalla AK, Hill MF, Singal PK. Role of oxidative stress in transition of hypertrophy to heart failure. J Am Coll Cardiol 1996; 28: 506-14.

[3] Hill MF, Singal PK Antioxidant and oxidative stress changes during heart failure subsequent to myocardial infarction in rats. Am J Pathol 1996; 148: 291-300.

[4] Touyz RM. Reactive oxygen species, vascular oxidative stress and redox signaling in hypertension: what is the clinical significance? Hypertension 2004; 44: 248-52.

[5] Redon J, Oliva MR, Tormos C, et al. Antioxidant activities and oxidative stress byproducts in human hypertension. Hypertension 2003; 41: 1096-101.

[6] Lassègue $B$, Griendling KK. Reactive oxygen species in hypertension. An update. Am J Hypertension 2004; 17: 852-60.

[7] Wang HD, Xu S, Johns DG, et al. Role of NADPH oxidase in the vascular hypertrophic and oxidative stress response to angiotensin II in mice. Circ Res 2001; 88: 947-53.

[8] Cifuentes ME, Rey FE, Carretero OA, Pagano PJ. Up-regulation of $\mathrm{p} 67^{\text {phox }}$ and gp9 $91^{\text {phox }}$ in aortas from angiotensin II- infused mice. Am J Physiol 2000; 279: H2234-40.

[9] Griendling KK, Minieri CA, Ollerenshaw JD, Alexander RW. Angiotensin II stimulates NADH and NADPH oxidase activity in cultured vascular muscle cells. Circ Res 1994; 74: 1141-8.

[10] Xie Z, Pimental DR, Lohan S, et al. Regulation of angiotensin IIstimulated osteopontin expression in cardiac microvascular endothelial cells: role of p24/p44 mitogen-activated protein kinase and reactive oxygen species. J Cell Physiol 2001; 188: 132-8.

[11] Nakamura K, Fushimi K, Kouchi H, et al. Inhibitory effects of antioxidants on neonatal rat cardiac myocyte hypertrophy induced by tumor necrosis factor- $\alpha$ and angiotensin II. Circulation 1998; 98 : 794-9.

[12] Siwik DA, Tzortzis JD, Pimental DR, et al. Inhibition of copperzinc superoxide dismutase induces cell growth, hypertrophic phenotype and apoptosis in neonatal rat cardiac myocytes in vitro. Circ Res 1999; 85: 147-53.

[13] Bataller R, Schwabe RF, Choi YH, et al. NADPH oxidase signal transduces angiotensin II in hepatic stellate cells and is critical in hepatic fibrosis. J Clin Invest 2003; 112: 1383-94.

[14] Touyz RM, Chen X, Tabet F, et al. Expression of a functionally active gp91 ${ }^{\text {phox }}$-containing neutrophil-type $\mathrm{NAD}(\mathrm{P}) \mathrm{H}$ oxidase in smooth muscle cells from human resistance arteries: regulation by angiotensin II. Circ Res 2002; 90: 1205-13.

[15] Rajagopalan S, Kurz S, Münzel T, et al. Angiotensin II-mediated hypertension in the rat increases vascular superoxide production via membrane NADH/NADPH oxidase activation. Contribution to alterations of vasomotor tone. J Clin Invest 1996; 97: 1916-23.

[16] Pagano PJ, Chanock SJ, Siwik DA, Colucci WS, Claerk JK. Angiotensin II induces p6 $7^{\text {phox }}$ mRNA expression and $\mathrm{NAD}(\mathrm{P}) \mathrm{H}$ oxidase superoxide generation in rabbit aortic adventitial fibroblasts. Hypertension 1998; 32: 331-7.

[17] Touyz RM, Schiffrin EL. Angiotensin II-stimulated superoxide production is mediated via phospholipidase $\mathrm{D}$ in human vascular smooth muscle cells. Hypertension 1999; 34: 976-82.

[18] Virdis A, Neves MF, Amiri F, Viel E, Touyz RM, Schiffrin EL. Spironolactone improves angiotensin-induced vascular changes and oxidative stress. Hypertension 2002; 40: 504-10.

[19] Hill MF, Singal PK. Right and left myocardial antioxidant responses during heart failure subsequent to myocardial infarction. Circulation 1997; 96: 2414-20.

[20] Zhan CD, Sindhu RK, Pang J, Ehdaie A, Vaziri ND. Superoxide dismutase, catalase and glutathione peroxidase in the spontaneously hypertensive rat kidney: effect of antioxidant-rich diet. J Hypertension 2004; 22: 2025-33.

[21] Fridovich I. Superoxide radical and superoxide dismutase. Ann Rev Biochem 1995; 64: 97-112.

[22] Wu R, Milette E, Wu L, de Champlain J. Enhanced superoxide anion formation in vascular tissues from spontaneously hypertensive and desoxycorticosterone acetate-salt hypertensive rats. J Hypertension 2001; 19: 741-8. 
[23] Pagano PJ, Ito Y, Tornheim K, Gallop PM, Tauber AI, Cohen RA. An NADPH oxidase superoxide-generating system in the rabbit aorta. Am J Physiol 1995; 268: H2274-80.

[24] Siwik DA, Pagano PJ, Colucci WS. Oxidative stress regulates collagen synthesis and matrix metalloproteinase activity in cardiac fibroblasts. Am J Physiol 2001; 280: C53-60.

[25] Zafari AM, Ushio-Fukai $\mathrm{M}$, Akers $\mathrm{M}$, et al. Role of NADH/NADPH oxidase-derived $\mathrm{H}_{2} \mathrm{O}_{2}$ in angiotensin II-induced vascular hypertrophy. Hypertension 1998; 32: 488-95.

[26] Vozenin-Brotons MC, Sivan V, Gault N, et al. Antifibrotic action of $\mathrm{Cu} / \mathrm{Zn}$ SOD is mediated by TGF- $\beta_{1}$ repression and phenotypic reversion of myofibroblasts. Free Radic Biol Med 2001; 30: 30-42.

[27] Oury TD, Chang LY, Marklund SL, Day BJ, Crapo JP. Immunocytochemical localization of extracellular superoxide dismutase in human lung. Lab Invest 1994; 70: 889-98.

[28] Petersen SV, Oury TD, Ostergaard L, et al. Extracellular superoxide dismutase binds to type I collagen and protects against oxidative fragmentation. J Biol Chem 2004; 279: 13705-10.

[29] Fattman CL, Chang LY, Termin TA, Petersen L, Enghild JJ, Oury TD. Enhanced bleomycin-induced pulmonary damage in mice lacking extracellular superoxide dismutase. Free Radic Biol Med 2003; 35: 763-71.

[30] Bendall JK, Cave AC, Heymes C, Gail N, Shah AM. Pivotal role of a gp91 ${ }^{\text {phox }}$-containing NADPH oxidase in angiotensin II-induced cardiac hypertrophy in mice. Circulation 2002; 105: 293-6.

[31] Belkhiri A, Richards C, Whaley M, McQueen SA, Orr FW. Increased expression of activated matrix metalloproteinase-2 by human endothelial cells after sublethal $\mathrm{H}_{2} \mathrm{O}_{2}$ expression. Lab Invest 1997; 77: 533-9.

[32] Pardo A, Barrios R, Maldonado V, et al. Gelatinases A and B are up-regulated in rat lungs by subacute hyperoxic pathogenetic implications. Am J Pathol 1998; 153: 833-44.

[33] Kawaguchi Y, Tanaka K, Okada T, et al. The effects of ultraviolet $\mathrm{A}$ and reactive oxygen species on the mRNA expression of 72-kDa type IV collagenase and its tissue inhibitor in cultured human dermal fibroblasts. Arch Derm Res 1996; 88: 39-44.

[34] Sun Y, Ratajska A, Zhou G, Weber KT. Angiotensin converting enzyme and myocardial fibrosis in the rat receiving angiotensin II or aldosterone. J Lab Clin Med 1993; 122: 395-403.

[35] Kato H, Suzuki H, Tajima S, et al. Angiotensin II stimulates collagen synthesis in cultured vascular smooth muscle cells. J Hypertension 1991; 9: 17-22.

[36] Wolf G, Haberstroh U, Neilson EG. Angiotensin II stimulates the proliferation and biosynthesis of type I collagen in cultured murine mesangial cells. Am J Pathol 1992; 140: 95-107.

[37] Border WA, Noble NA. Interactions of transforming growth factor$\beta$ and angiotensin II in renal fibrosis. Hypertension 1998; 31: 1818 .

[38] Kagami S, Border WA, Miller DE, Noble NA. Angiotensin II stimulates extracellular matrix protein synthesis through interaction of transforming growth factor- $\beta$ expression in rat glomerular mesangial cells. J Clin Invest 1994; 93: 2431-7.

[39] Sano H, Okada H, Kawaguchi H, Yasuda H. Increased angiotensin II-stimulated collagen synthesis in cultured cardiac fibroblasts from spontaneously hypertensive rats. Circulation 1991; 84: II48.

[40] Villarreal FJ, Kim NN, Ungab GD, Printz MP, Dillmann WH. Identification of functional angiotensin II receptors on rat cardiac fibroblasts. Circulation 1993; 88: 2849-61.

[41] Crabos M, Roth M, Hahn AW, Erne P. Characterization of angiotensin II receptors in cultured rat fibroblasts. Coupling to signaling systems and gene expression. J Clin Invest 1994; 93 : 2372-8.

[42] Brilla CG, Zhou G, Matsubara L, Weber KT. Collagen metabolism in cultured rat cardiac fibroblasts: response to angiotensin II and aldosterone. J Mol Cell Cardiol 1994; 26: 809-20.

[43] Lijnen P, Petrov V, Fagard R. Angiotensin II-induced stimulation of collagen secretion and production in cardiac fibroblasts is mediated via angiotensin II subtype 1 receptors. J Renin Angiotensin Aldosterone Syst 2001; 2: 117-22.

[44] Brilla CG, Scheer C, Rupp H. Renin-angiotensin system and myocardial collagen matrix: Modulation of cardiac fibroblast function by angiotensin II type 1 receptor antagonism. J Hypertens 1997; 15: S13-8.

[45] Crawford DC, Crobanian AV, Brecher P. Angiotensin II induces fibronectin expression associated with cardiac fibrosis in the rat. Circ Res 1994; 74: 727-39.

[46] Kim S, Ohta K, Hamaguchi A, et al. Angiotensin II type 1 receptor antagonist inhibits the gene expression of transforming growth factor- $\beta_{1}$ and extracellular matrix in cardiac and vascular tissues of hypertensive rats. J Pharmacol Exp Ther 1995; 273: 509-15.

[47] Brilla CG, Rupp H, Funck R, Maisch B. The renin-angiotensinaldosterone system and myocardial collagen matrix remodeling in congestive heart failure. Eur Heart J 1995; 16: S107-9.

[48] Campbell SE, Janicki JS, Weber KT. Temporal differences in fibroblast proliferation and phenotype expression in response to chronic administration of angiotensin II and aldosterone. J Mol Cell Cardiol 1995; 27: 1545-60.

[49] Tan LB, Jalil JE, Pick R, Janicki JS, Weber KT. Cardiac myocyte necrosis induced by angiotensin II. Circ Res 1991; 69: 1185-95.

[50] Sadoshima J, Izumo S. Molecular characterization of angiotensin II-induced hypertrophy of cardiac myocytes and hyperplasia of cardiac fibroblasts: critical role of $\mathrm{AT}_{1}$ receptor subtype. Circ Res 1993; 73: 413-23.

[51] Schorb W, Booz GW, Dostal DE, Conrad KM, Chang KC, Baker KM. Angiotensin II is mitogenic in neonatal rat cardiac fibroblasts. Circ Res 1995; 72: 1245-54.

[52] Matsubara H, Kanasaki M, Murasawa S, Tsukuguchi Y, Nio Y, Inada M. Differential gene expression and regulation of angiotensin II receptor subtypes in rat cardiac fibroblasts and cardiomyocytes in culture. J Clin Invest 1994; 93: 1592-601.

[53] Gallagher AM, Bahnson TD, Yu H, Kim NN, Printz MP. Species variability in angiotensin receptor expression by cultured cardiac fibroblasts and the infarcted heart. Am J Physiol 1998; 274: H8019.

[54] Kupfahl C, Pink D, Friedrich K, et al. Angiotensin II directly increases transforming growth factor- $\beta_{1}$ and osteopontin and indirectly affects collagen mRNA expression in the human heart. Cardiovasc Res 2000; 46: 463-75.

[55] Lee AA, Dillmann WH, McCulloch AD, Villareal FJ. Angiotensin II stimulates the autocrine production of transforming growth factor- $\beta_{1}$ in adult rat cardiac fibroblasts. J Mol Cell Cardiol 1995; 27: 2347-57.

[56] Fisher SA, Absher M. Norepinephrine and angiotensin II stimulate secretion of TGF- $\beta_{1}$ by neonatal rat cardiac fibroblasts in vitro. Am J Physiol 1995; 268: C91-107.

[57] Gibbons GH, Pratt RE, Dzau VJ. Vascular smooth muscle cell hypertrophy versus hyperplasia. Autocrine transforming growth- $\beta_{1}$ expression determines growth response to angiotensin II. J Clin Invest 1992; 90: 456-61.

[58] Koibuchi Y, Lee WS, Gibbons GH, Pratt RE. Role of transforming growth factor- $\beta_{1}$ in the cellular response to angiotensin II. Hypertension 1993; 22: 1046-50.

[59] Campbell SE, Katwa LC. Angiotensin II stimulated expression of transforming growth factor- $\beta_{1}$ in cardiac fibroblasts and myofibroblasts. J Mol Cell Cardiol 1997; 29: 1947-58.

[60] Nagasawa K, Zimmerman R, Westernachter D, Schaper J. Angiotensin II induced collagen mRNA expression in cardiac fibroblasts depends on autocrine production of transforming growth factor-beta. J Am Coll Cardiol 1994; 23: 43A

[61] Petrov V, Fagard R, Lijnen P. Stimulation of collagen production by transforming growth factor- $\beta_{1}$ during differentiation of cardiac fibroblasts to myofibroblasts. Hypertension 2002; 39: 258-63.

[62] Petrov V, Fagard R, Lijnen P. Transforming growth factor- $\beta_{1}$ induces angiotensin converting enzyme synthesis in rat cardiac fibroblasts during their differentiation to myofibroblasts. J Renin Angiotensin Aldosterone Syst 2000; 1: 342-52.

[63] Yamaguchi H, Kim S, Nishikimi T, Takeuchi K, Takeda T. Contribution of cardiac renin-angiotensin system to ventricular remodeling in myocardial-infarcted rats. J Mol Cell Cardiol 1993; 25: $1369-80$.

[64] Border WA, Noble NA. Transforming growth factor- $\beta_{1}$ in tissue fibrosis. N Engl J Med 1994; 331: 1286-92. 
[65] Weber KT. Extracellular matrix remodeling in heart failure. A role of de novo angiotensin II generation. Circulation 1997; 96: 406582.

[66] Schroter-Kermani C, Ochsner-Welpelo I, Kittelberger R. An inhibition ELISA for the quantification of collagen type I and type II in cyanogen bromide-digested tissues using fragments-directed antibodies. Immunol Invest 1990; 19: 75-91.

[67] Lijnen P, Papparella I, Petrov V, Semplicini A, Fagard R. Angiotensin II-stimulated collagen production in cardiac fibroblasts is mediated by reactive oxygen species. J Hypertens 2006; 24: 75766

[68] Stolk J, Hiltermann TJN, Dijkman JH, Verhoeven AJ. Characteristics of the inhibition of NADPH oxidase activation in neutrophils by apocynin, a methoxy-substitiuted catechol. Am J Respir Cell Mol Biol 1994; 11: 95-102.

[69] Doussière J, Vignais PV. Diphylene iodonium as an inhibitor of the NADPH oxidase complex of bovine neutrophils. Factors controlling the inhibitory potency of diphenylene iodonium in a cell-free system of oxidase activation. Eur J Biochem 1992; 208: 61-71

[70] Peng J, Gurantz D, Tran V, Cowling RT, Greenberg BH. Tumor necrosis factor-alpha-induced AT receptor upregulation enhances angiotensin II-mediated cardiac fibroblasts responses that favor fibrosis. Circ Res 2002; 91: 1119-26.

[71] Seeger H, Lippert C, Wallwiener D, Mueck AO. Valsartan and candesartan can inhibit deteriorating effects of angiotensin II on coronary endothelial function. J Renin Angiotensin Aldosterone Syst 2001; 2: 141-3

[72] Rouet-Benzineb P, Gontero B, Dreyfus P, Lafuma C. Angiotensin II induces nuclear factor-kappa B activation in cultured neonatal rat cardiomyocytes through protein kinase $\mathrm{C}$ signaling pathway. J Mol Cell Cardiol 2000; 32: 1767-78.

[73] Solini A, Santini E, Ferrannini E. Enhanced angiotensin IImediated effects in fibroblasts of patients with familial hypercholesterolemia. J Hypertension 2005; 23: 367-74.

[74] Virdis A, Neves MF, Amiri F, Touyz RM, Schiffrin EL. Role of $\mathrm{NAD}(\mathrm{P}) \mathrm{H}$ oxidase on vascular alterations in angiotensin II-infused mice. J Hypertens 2004; 22: 535-42.

[75] Park YM, Park MY, Suh YL, Park JB. NAD(P)H oxidase inhibitor prevents blood pressure elevation and cardiovascular hypertrophy in aldosterone-infused rats. Biochem Biophys Res Commun 2004; 313: 812-7.

[76] Lijnen P, Petrov V. Induction of cardiac fibrosis by aldosterone. J Mol Cell Cardiol 2000; 32: 865-79.

[77] Lijnen P, Petrov V. Renin angiotensin system, hypertrophy and gene expression in cardiac myocytes. J Mol Cell Cardiol 1999; 31: 949-70.

[78] Rey FE, Cifuentes ME, Kiarash A, Quinn MT, Pagano PJ. Novel competitive inhibitor of $\mathrm{NAD}(\mathrm{P}) \mathrm{H}$ oxidase assembly attenuates vascular $\mathrm{O}_{2}^{-}$and systolic blood pressure in mice. Circ Res 2001; 89: 408-14.

[79] Sun Y, Zhang J, Lu L, Chen SS, Quinn MT, Weber KT. Aldosterone-induced inflammation in the rat heart: role of oxidative stress. Am J Pathol 2002; 161: 1773-81.

[80] Iglarz M, Touyz RM, Viel EC, Amiri F, Schiffrin EL. Involvement of oxidative stress in the profibrotic action of aldosterone. Interaction with the renin-angiotensin system. Am J Hypertens 2004; 17: 597-603.

[81] Chen K, Chen J, Li D, Zhang X, Mehta JL. Angiotensin II regulation of collagen type I expression in cardiac fibroblasts: modulation by PPAR- $\gamma$ ligand pioglitazone. Hypertension 2004; 44: 655-61.

[82] Sousa T, Pinto D, Morato M. Effect of the NADPH oxidase inhibitor apocynin on systolic blood pressure and on vascular antioxidant defenses in hypertensive rats with activation of the reninangiotensin-system. J Hypertens 2005; 23: S361.

[83] Thannickal VJ, Fanburg BL. Activation of an $\mathrm{H}_{2} \mathrm{O}_{2}$-generating NADH oxidase in human lung fibroblasts by transforming growth factor $\beta_{1}$. J Biol Chem 1995; 270: 30334-8.

[84] Ellmark SH, Dusting GJ, Fui MN, Guzzo-Pernell N, Drummond GR. The contribution of NOX4 to NADPH oxidase activity in mouse vascular smooth muscle cells. Cardiovasc Res 2005; 65: 495-504.

[85] Meier B, Radeke HH, Selle S, et al. Human fibroblasts release reactive oxygen species in response to interleukin-1 or tumour necrosis factor- $\alpha$. Biochem J 1989; 263: 539-45.

[86] Nakagami H, Takemoto M, Liao JK. NADPH oxidase-derived superoxide anion mediates angiotensin II-induced cardiac hypertrophy. J Mol Cell Cardiol 2003; 35: 851-9.

[87] Ding Y, Chen ZJ, Liu S, Che D, Vetter M, Chang CH. Inhibition of NOX4 activity by plumbagin, a plant-derived bioactive naphtoquinone. J Pharm Pharmacol 2005; 57: 111-6.

[88] Brightman AO, Wang J, Miu RK, et al. A growth factor- and hormone-stimulated NADH oxidase from rat liver plasma membrane. Biochim Biophys Acta 1992; 1105: 109-17.

[89] Sano M, Fukuda K, Sato T, et al. ERK and p38 MAPK, but not $\mathrm{NF}-\kappa \mathrm{B}$, are critically involved in reactive oxygen species-mediated induction of IL-6 by angiotensin II in cardiac fibroblasts. Circ Res 2001; 89: 661-9.

[90] Cheng TH, Cheng PY, Shih NL, Chen IB, Wang DL, Chen JJ. Involvement of reactive oxygen species in angiotensin II-induced endothelin-1 gene expression in rat cardiac fibroblasts. J Am Coll Cardiol 2003; 42: 1845-54.

[91] Touyz RM, He G, El Mabrouk M, Schiffrin EL. p38 MAP Kinase regulates vascular smooth muscle cell collagen synthesis by angiotensin II in SHR but not in WKY. Hypertension 2001; 37: 574-80.

[92] Xie Z, Singh M, Singh K. ERK1/2 and JNKs, but not p38 kinase, are involved in reactive oxygen species-mediated induction of osteopontin gene expression by angiotensin II and interleukin-1beta in adult rat cardiac fibroblasts. J Cell Physiol 2004; 198: 399-407.

[93] Li N, Karin M. Is NF-KB the sensor of oxidative stress? FASEB J 1999; 13: 1137-43

[94] Touyz RM. Reactive oxygen species as mediators of calcium signaling by angiotensin II: implications in vascular physiology and pathophysiology. Antioxid Redox Signal 2005; 7: 1302-14.

[95] Shivakumar K, Kumaran C. L-Type calcium channel blockers and EGTA enhance superoxide production in cardiac fibroblasts. J Mol Cell Cardiol 2001; 33: 373-7.

[96] Kumaran C, Shivakumar K. Superoxide-mediated activation of cardiac fibroblasts by serum factors in hypomagnesemia. Free Radic Biol Med 2001; 31: 882-6.

[97] Cucoranu I, Clempus R, Dikalova A, et al. NAD(P)H oxidase 4 mediates transforming growth factor- $\beta_{1}$-induced differentiation of cardiac fibroblasts into myofibroblasts. Circ Res 2005; 97: 900-7.

[98] Dikalov SI, Dikalova AE, Bikineyeva AT, Schmidt HHHW, Harrison DG, Griendling KK. Distinct roles of Nox 1 and Nox4 in basal and angiotensin II-stimulated superoxide and hydrogen peroxide production. Free Rad Biol Med 2008; 45: 1340-51.

[99] Lijnen P, Petrov V, van Pelt J, Fagard R. Inhibition of superoxide dismutase induces collagen production in cardiac fibroblasts. Am J Hypertens 2008; 21: 1129-36.

[100] Marklund SL. Extracellular superoxide dismutase and other superoxide dismutase isoenzymes in tissues from nine mammalian species. Biochem J 1984; 222: 649-55.

[101] Chabrashvili T, Kitiyakara C, Blau J, et al. Effect of ANG II type 1 and 2 receptors on oxidative stress, renal NADPH oxidase and SOD expression. Am J Physiol 2003; 285: R117-24.

[102] Welch WJ, Chabrashvii T, Solis G, et al. Role of extracellular superoxide dismutase in the mouse angiotensin slow pressor response. Hypertension 2006; 48: 934-41.

[103] Zhao W, Ahokas RA, Weber KT, Sun Y. Angiotensin II-induced cardiac molecular and cellular events; role of aldosterone. Am J Physiol 2006; 291: H336-43.

[104] Fukai T, Siegfried MR, Ushio-Fukai M, Griendling KK, Harrison DG. Modulation of extracellular superoxide dismutase expression by angiotensin II and hypertension. Circ Res 1999; 85: 23-8.

[105] Strälin P, Marklund SL. Vasoactive factors and growth factors alter vascular smooth muscle cell EC-SOD expression. Am J Physiol 2001; 281: H1621-29. 
[106] Didion SP, Kinzenbaw DA, Faraci FM. Critical role for CuZnsuperoxide dismutase in preventing angiotensin II-induced endothelial dysfunction. Hypertension 2005; 46: 1147-53.

[107] Lijnen P, van Pelt J, Fagard R. Down-regulation of manganese superoxide dismutase by angiotensin II in cardiac fibroblasts . Am J Hypertension 2010; 23: 1128-35.

[108] Guo W, Adachi T, Matsui R, et al. Quantitative assessment of tyrosine nitration of manganese superoxide dismutase in angiotensin II-infused rat kidney. Am J Physiol 2003; 285: H1396403 .

[109] Zhao W, Chen SS, Chen Y, Ahokas RA, Sun Y. Kidney fibrosis in hypertensive rats: role of oxidative stress. Am J Nephrol 2008; 28 : 548-54.

[110] Gongora MC, Qin Z, Laude K, et al. Role of extracellular superoxide dismutase in hypertension. Hypertension 2006; 48: 473 81 .

[111] Chandramohan G, Bai Y, Norris K, Rodriguez-Iturbe B, Vaziri ND. Effects of dietary salt on intrarenal angiotensin system, NAD(P)H oxidase, COX-2, MCP-1 and PAI-1 expressions and NF$\kappa \mathrm{B}$ activity in salt-sensitive and resistant rat kidneys. Am J Nephrol 2008; 28: 158-67.

[112] Onozato ML, Tojo A, Kobayashi N, Goto A, Matsuoka H, Fujita T. Dual blockade of aldosterone and angiotensin II additively suppresses TGF- $\beta$ and NADPH oxidase in the hypertensive kidney. Nephrol Dial Transplant 2007; 22: 1314-22.

[113] de Cavanagh EM, Toblli JE, Ferder L, Piotrkowski B, Stella I, Inserra F. Renal mitochondrial dysfunction in spontaneously hypertensive rats is attenuated by losartan and not by amlodipine. Am J Physiol 2006; 290: R1616-25.

[114] Lu L, Quinn MT, Sun Y. Oxidative stress in the infarcted heart: role of de novo angiotensin II production. Biochem Biophys Res Commun 2004; 325: 943-91.

[115] Khaper N, Kaur K, Li T, Farahmand F, Singal PK. Antioxidant enzyme gene expression in congestive heart failure following myocardial infarction. Mol Cell Biochem 2003; 251: 9-15.

[116] Shigenaga MK, Hagen TM, Ames BN. Oxidative damage and mitochondrial decay in aging. Proc Natl Acad Sci USA 1994; 91: 10771-8.

[117] Hwang IK, Yoo KY, Kim DW, et al. Changes in the expression of mitochondrial peroxiredoxin and thioredoxin in neurons and their protective effects in experimental ischemic damage. Free Rad Biol Med 2010; 48: 1242-51.

[118] Suematsu N, Tsutsui H, Wen J, et al. Oxidative stress mediates tumor necrosis factor- $\alpha$-induced mitochondrial DNA damage and dysfunction in cardiac myocytes. Circulation 2003; 107: 1418-23.

[119] Ide T, Tsutsui H, Hayashidani S, et al. Mitochondrial DNA damage and dysfunction associated with oxidative stress in failing hearts after myocardial infarction. Circ Res 2001; 88: 529-35.

[120] Zhang GX, Lu XM, Kimura S, Nishiyama A. Role of mitochondria in angiotensin II-induced reactive oxygen species and mitogenactivated protein kinase activation. Cardiovasc Res 2007; 76: 20412.

[121] Gustafsson AB, Gottlieb RA. Heart mitochondria: gates of life and death. Cardiovasc Res 2008; 77: 334-48.

[122] Guellich A, Damy T, Lecarpentier Y, et al. Tempol, a Mn-SOD mimetic, prevents the cardiac contractile dysfunction in PPARalpha $^{-/-}$mice. J Mol Cell Cardiol 2008; 42: S110.

[123] Li Y, Huang TT, Carlson EJ, et al. Dilated cardiomyopathy and neonatal lethality in mutant mice lacking manganese superoxide dismutase. Nat Genet 1995; 11: 576-81.

[124] Nojiri H, Shimizu T, Funakoshi M, et al. Oxidative stress causes heart failure with impaired mitochondrial respiration. J Biol Chem 2006; 281: 33789-801.

[125] Wenzel P, Schuhmacher S, Kienhöfer J, et al. Manganese superoxide dismutase and aldehyde dehydrogenase deficiency increase mitochondrial oxidative stress and aggravate agedependent vascular function. Cardiovasc Res 2008; 80: 280-9.

[126] Ballinger SW, Patterson C, Knight-Lozano CA, et al. Mitochondrial integrity and function in atherogenesis. Circulation 2002; 106: 544-9.
[127] Gutierrez J, Ballinger SW, Darley-Usmar VM, Landar A. Free radicals, mitochondria and oxidized lipids. Circ Res 2006; 99: 92432.

[128] Miller JD, Peotta VA, Chu Y, et al. MnSOD protects against COX1-mediated endothelial dysfunction in chronic heart failure. Am J Physiol 2010; 298: H1600-07.

[129] Chen Z, Siu B, Ho YS, et al. Over-expression of MnSOD protects against myocardial ischemia/reperfusion injury in transgenic mice. J Mol Cell Cardiol 1998; 30: 2281-9.

[130] Shen X, Zheng S, Metreveil NS, Epstein PN. Protection of cardiac mitochondria by over-expression of $\mathrm{Mn}-\mathrm{SOD}$ reduces diabetic cardiomyopathy. Diabetes 2006; 55: 798-805.

[131] Li L, Fink GD, Watts SW, et al. Endothelin-1 increases vascular superoxide via NADPH oxidase pathway in low-renin hypertension. Circulation 2003; 107: 1053-8.

[132] Nozoe M, Hirooka Y, Koga Y, et al. Mitochondria-derived reactive oxygen species mediate sympathoexcitation induced by angiotensin II in the rostral ventrolateral medulla. J Hypertension 2008; 26: 2176-84.

[133] Kim A, Joseph S, Khan A, Epstein CJ, Sobel R, Huang TT. Enhanced expression of mitochondrial superoxide dismutase leads to prolonged in vivo cell cycle progression and up-regulation of mitochondrial thioredoxin. Free Radic Biol Med 2010; 48: 150112.

[134] Sarsour EH, Venkataraman S, Kalen AL, Oberley LW, Goswami PC. Manganese superoxide dismutase activity regulates transition between quiescent and proliferative growth. Aging Cell 2008; 7: 405-17.

[135] Kim A, Zhong W, Oberley TD. Reversible modulation of cell cycle kinetics in NH/3T3 mouse fibroblasts by inducible over-expression of mitochondrial manganese superoxide dismutase. Antioxid Redox Signal 2004; 6: 489-500.

[136] Matsushima S, Ide T, Yamato M, et al. Over-expression of mitochondrial peroxiredoxin-3 prevents left ventricular remodeling and failure after myocardial infarction in mice. Circulation 2006; 113: $1779-86$.

[137] Marin-Garcia J, Goldenthal MJ. Mitochondrial centrality in heart failure. Heart Fail Rev 2008; 13: 137-50.

[138] Sam F, Kerstetter DL, Pimental DR, et al. Increased reactive oxygen species production and functional alterations in antioxidant enzymes in human failing myocardium. J Card Fail 2005; 11: 47380 .

[139] Karamanlidis G, Nascimben L, Couper GS, Shekar PS, del Monte F, Tian R. Defective DNA replication impairs mitochondrial biogenesis in human failing hearts. Circ Res 2010; 106: 15471-48.

[140] Larkin JE, Frank BC, Gaspard RM, Duka I, Gavras H, Quackenbush J. Cardiac transcriptional response to acute and chronic angiotensin II treatment. Physiol Genomics 2004; 18: 15266.

[141] Kienhöfer J, Häussler DJF, Ruckelshausen F, et al. Association of mitochondrial antioxidant enzymes with mitochondrial DNA as integral nucleoid constituents. FASEB J 2009; 23: 2034-44.

[142] Li PF, Dietz R, von Harsdorf R. Superoxide induces apoptosis in cardiocytes, but proliferation and expression of transforming growth factor- $\beta 1$ in cardiac fibroblasts. FEBS Lett 1999; 448: 20610 .

[143] Tsutsui H, Kimugawa S, Matsushima S. Mitochondrial oxidative stress and dysfunction in myocardial remodeling. Cardiovasc Res 2009; 81: 449-56.

[144] Kang SW, Chae HZ, Seo MS, Kim K, Baines IC, Rhee SG. Mammalian peoxiredoxin isoforms can reduce hydrogen peroxide generated in response to growth factors and tumor necrosis factora. J Biol Chem 1998; 273: 6297-302.

[145] Fatma N, Singh DP, Schinohara T, Chylack LT. Transcriptional regulation of the antioxidant protein 2 gene, a thiol-specific antioxidant, by lens epithelium-derived growth factor to protect cells from oxidative stress. J Biol Chem 2001; 276: 48899-907.

[146] Fuji T, Fuji J, Taniguchi N. Augmented expression of peroxiredoxin VI in rat lung and kidney after birth implies an antioxidative role. Eur J Biochem 2001; 268: 218-25. 
[147] Salmon M, Dedessus Le Montier J, et al. Role of the PLA $2^{-}$ independent peroxiredoxin VI activity in the survival of immortalized fibroblasts to cytotoxic oxidative stress. FEBS Lett 2004: 557: 26-32.

[148] Rhee SG, Chae HZ, Kim K. Peroxiredoxins: a historical overview and speculative preview of novel mechanisms and emerging concepts in cell signaling. Free Radic Biol Med 2005; 38: 1543-52.

[149] Ebrahimian T, Touyz RM. Thioredoxin in vascular biology: role in hypertension. Antioxid Redox Signal 2008; 10: 1127-35.

[150] Watabe S, Hiroi T, Yamamoto Y, et al. SP-22 is a thioredoxindependent peroxide reductase in mitochondria. Eur $\mathrm{J}$ Biochem 1997; 249: 52-60.

[151] Bryk R, Griffin P, Nathan C. Peroxynitrite reductase activity of bacterial peroxiredoxins. Nature 2000; 407: 211-5.

[152] Lijnen P, van Pelt J, Fagard R. Regulation of manganese superoxide dismutase expression by angiotensin II in cardiac fibroblasts. J Clin Hypertension 2010; 12: A106.

[153] Wood-Allum R, Barber SC, Kirby J, et al. Impairment of mitochondrial anti-oxidant defense in SOD1-related motor neuron injury and amelioration by ebselen. Brain 2006; 129: 1693-1709.

[154] Oh YK, Lee TB, Choi CH. Anti-oxidant adaptation in the AML cells supersensitive to hydrogen peroxide. Biochem Biophys Res Commun 2004; 319: 41-5

[155] Hattori F, Murayama N, Noshita T, Oikawa S. Mitochondrial peroxiredoxin-3 protects hippocampal neurons from excitotoxic injury in vivo. J Neurochem 2003; 86: 860-8.

[156] Brixius K, Schwinger RHG, Hoyer F, et al. Isoform-specific downregulation of peroxiredoxin in human failing myocardium. Life Sciences 2007; 81: 823-31.

[157] Onorato TM, Brown PW, Morris PL. Mono-(2-ethylhexyl) phthalate increases spermatocyte mitochondrial peroxiredoxin-3 and cyclooxygenase 2. J Androl 2008; 29: 293-303.

[158] Chang TS, Cho Cs, Park S, Yu S, Kang SW, Rhee SG. Peroxiredoxin III, a mitochondrion-specific peroxidase, regulates apoptotic signaling by mitochondria. J Biol Chem 2004; 279: 41975-84.

[159] Li L, Shoji W, Takano H, et al. Increased susceptibility of MER5 (peroxiredoxin III) knockout mice to LPS-induced oxidative stress. Biochem Biophys Res Commun 2007; 355: 715-21.

[160] Li L, Kaifu T, Obinata M, Takai T. Peroxiredoxin III-deficiency sensitizes macrophages to oxidative stress. J Biochem 2009; 145: 425-7.

[161] Suematsu N, Tsutsui H, Wen J, et al. Oxidative stress mediates tumor necrosis factor- $\alpha$-induced mitochondrial DNA damage and dysfunction in cardiac myocytes. Circulation 2003; 107: 1418-23.

[162] Ide T, Tsutsui H, Hayashidani S, et al. Mitochondrial DNA damage and dysfunction associated with oxidative stress in failing hearts after myocardial infarction. Circ Res 2001; 88: 529-35

[163] Matsushima S, Ide T, Yamato M, et al. Over-expression of mitochondrial peroxiredoxin-3 prevents left ventricular remodeling and failure after myocardial infarction in mice. Circulation 2006; 113: $1779-86$

[164] Chen L, Na R, Gu M, et al. Reduction of mitochondrial $\mathrm{H}_{2} \mathrm{O}_{2}$ by over-expressing peroxiredoxin 3 improves glucose tolerance in mice. Aging Cells 2008; 7: 866-70.

[165] Kohlhaus M, Liu T, Knopp A, et al. Elevated cytosolic $\mathrm{Na}^{+}$ increases mitochondrial formation of reactive oxygen species in failing cardiac myocytes. Circulation 2010; 121: 1606-13.

[166] Chiribau CB, Cheng L, Cucoranu IC, Yu YS, Clempus RE, Sorescu D. FOXO3a regulates peroxredoxin III expression in human cardiac fibroblasts. J Biol Chem 2008; 283: 8211-17.

[167] Kops GJPL, Dansen TB, Polderman PE, et al. Forkhead transcription factor FOXO3a protects quiescent cells from oxidative stress. Nature 2002; 419: 316-21.

[168] Li M, Chiu JF; Mossmann BT, Fukagawa NK. Down-regulation of manganese-superoxide dismutase through phosphorylation of FOXO3a by Akt in explanted vascular smooth muscle cells from old rats. J Biol Chem 2006; 281: 40429-39.

[169] Tan WQ, Wang K, Lv DY, Li PF. Foxo3a inhibits cardiomyocyte hypertrophy through transactivating catalase. J Biol Chem 2008; 288: 29730-9.
[170] Rudi R, Turrens JF, Chang LY, Bush KM, Crapo JD, Freeman BA. Detection of catalase in rat heart mitochondria. J Biol Chem 1991; 266: 22028-34

[171] Cox AG, Winterbourn CC, Hampton MB. Mitochondrial peroxiredoxin involvement in antioxidant defense and redox signaling. Biochem J 2010; 425: 313-25.

[172] Tian B, Liu J, Bittermann P, Bache RJ. Angiotensin II modulates nitric oxide-induced cardiac fibroblast apoptosis by activation of Akt/PKB. Am J Physiol 2003; 285: H1105-12.

[173] Majid DS, Nishiyama A. Nitric oxide blockade enhance renal responses to superoxide dismutase inhibition in dogs. Hypertension 2002; 39: 293-7.

[174] Zou AP, Li N, Cowley AW Jr. Production and actions of superoxide in the renal medulla. Hypertension 2001; 37: 547-53.

[175] Li WG, Miller FJ Jr, Zhang HJ, Spitz DR, Oberley LW, Weintraub $\mathrm{NL} . \mathrm{H}_{2} \mathrm{O}_{2}$-induced $\mathrm{O}_{2}{ }^{-}$production by a non-phagocytic NAD(P)H oxidase causes oxidant injury. J Biol Chem 2001; 276: 29251-6.

[176] Miller AA, Drummond GR, Schmidt HH, Sobey CG. NADPH oxidase activity and function are profoundly greater in cerebral versus systemic arteries. Circ Res 2005; 97:1055-62.

[177] Colston JT, de la Rosa SD, Strader JR, Anderson MA, Freeman GL. $\mathrm{H}_{2} \mathrm{O}_{2}$ activates Nox4 through $\mathrm{PLA}_{2}$-dependent arachidonic acid production in adult cardiac fibroblasts. FEBS Lett 2005; 579: 2533 40

[178] Luo J, Xuan YT, Gu Y, Prabhu SD. Prolonged oxidative stress inverts the cardiac force-frequency relation : role of altered calcium handling and myofilament calcium responsiveness. J Mol Cell Cardiol 2006; 40: 64-75

[179] Asaba K, Tojo A, Onozato ML, Goto A, Fujiota T. Double-edged action of SOD mimetic in diabetic nephropathy. J Cardiovasc Pharmacol 2007; 49: 13-9.

[180] Zhang GX, Kimura S, Nishiyama A, et al. Cardiac oxidative stress in acute and chronic isoproterenol-infused rats. Cardiovasc Res 2005; 65: 230-8

[181] Van Empel VPM, Bertrand AT, van Oort RJ, et al. EUK-8, a superoxide dismutase and catalase mimetic, reduces cardiac oxidative stress and ameliorates pressure overload-induced heart failure in the harlequin mouse mutant. J Am Coll Cardiol 2006; 48: 824-32.

[182] Laursen JB, Rajagopalan S, Galis Z, Tarpey M, Freeman BA, Harrison DG. Role of superoxide in angiotensin II-induced but not catecholamine-induced hypertension. Circulation 1997; 95: 588-93.

[183] Tsubokawa T, Jadhav V, Solaroglu I, Shiokawa Y, Konishi Y, Zhang JH. Lecithinized superoxide dismutase improves outcomes and attenuates focal cerebral ischemic injury via antiapoptotic mechanisms in rats. Sroke 2007; 38: 1057-62.

[184] Tamagawa K, Taooka Y, Maeda K, Hiyama K, Ishioka S, Yamakido M. Inhibitory effects of a lecithinized superoxide dismutase on bleomycin-induced pulmonary fibrosis in mice. Am $\mathrm{J}$ Respir Crit Care Med 2000; 161: 1279-84.

[185] Delanian S, Baillet F, Huart J, Lefaix JL, Maulard C, Housset M. Successful treatment of radiation-induced fibrosis using liposomal $\mathrm{Cu} / \mathrm{Zn}$ superoxide dismutase: clinical trial. Radiother Oncol 1994; 32: 12-20.

[186] Benyahia B, Campana F, Perdereau B, Gez E, Fourquet A, Magdelenat $\mathrm{H}$. Effects of SOD topical treatment on human skin radiofibrosis; a pathological study. Breast 1996; 5: 75-81.

[187] Lefaix JL, Delanian S, Leplat JJ, et al. Successful treatment of radiation-induced fibrosis using $\mathrm{CuZn}$ SOD and Mn SOD: an experimental study. Int J Radiat Oncol Biol Phys 1996; 35: 305-12.

[188] An SJ, Boyd R, Zhu M, Chapman A, Pimentel DR, Wang HD NADPH oxidase mediates angiotensin II-induced endothelin-1 expression in vascular adventitial fibroblasts. Cardiovasc Res 2007; 75: 702-9.

[189] Lovelock JD, Baker AH, Gao F, et al. Heterogenous effects of tissue inhibitors of matrix metalloproteinases on cardiac fibroblasts. Am J Physiol 2005; 288: H461-8.

[190] Bergman MR, Cheng S, Honbo N, Piacentini L, Karliner JS, Lovett DH. A functional activating protein 1 site regulates matrix metalloproteinase 2 transcription by cardiac cells through 
interactions with junB-Fra1 and JunB-FosB heterodimers. Biochem J 2003; 369: 485-96.

[191] Takenaka H, Kihara Y, Iwanaga Y, Onozawa Y, Toyokuni S, Kita T. Angiotensin II, oxidative stress and extracellular matrix degradation during transition to LV failure in rats with hypertension. J Mol Cell Cardiol 2006; 41: 989-97.

[192] Bergman MR, Teerlink JR, Mahimkar R, et al. Cardiac matrix metalloproteinase-2 expression independently induces marked ventricular remodeling and systolic dysfunction. Am J Physiol 2007; 292: H1847-60.

[193] Gunja-Smith Z, Morales AR, Romanelli R, Woesner JF Jr. Remodeling of human myocardial collagen in idiopathic dilated cardiomyopathy. Role of metalloproteinases and pyridinoline cross-links. Am J Pathol 1996; 148: 1639-48.

[194] Matsusaka Y, Ikeuchi M, Matsushima S, et al. Selective disruption of MMP2 gene enhances myocardial inflammation and dysfunction in mice with cytokine-induced cardiomyopathy. Am J Physiol 2005; 289: H1858-64.
[195] Kim HE, Dalal SS, Young E, Legato MJ, Weisfeldt MI, D'Armiento J. Disruption of the myocardial extracellular matrix leads to cardiac dysfunction. J Clin Invest 2000; 106: 857-66.

[196] Henderson BC, Tyagi SC. Oxidative mechanism and homeostasis of proteinase/antiproteinase in congestive heart failure. J Mol Cell Cardiol 2006; 41: 959-62.

[197] Seltzre J1, Eisen AZ. Native type I collagen is not a substrate for matrix metalloproteinase-2. J Invest Dermatol 1999; 112: 993-94.

[198] Tam EM, Moore TR, Butler GS, Overall CM. Characterization of the distinct collagen binding, helicase and cleavage mechanisms of matrix metalloproteinase 2 and 14 (gelatinase A and MT1-MMP): the differential roles of the MMP hemopoxin c domains and the MMP-2 fibronectin type II modules in collagen triple helicase activities. J Biol Chem 2004; 279: 43336-44.

[199] Fearon IM, Faux SP. Oxidative stress and cardiovascular disease: Novel tools give (free) radical insight. J Mol Cell Cardiol 2009; 47: 372-80.

[200] Burelle Y, Khairallah M, Ascah A, et al. Alterations in mitochondrial function as a harbinger of cardiomyopathy: lessons from the dystrophic heart. J Mol Cell Cardiol 2010; 48: 310-21.

(C) Lijnen et al.; Licensee Bentham Open.

This is an open access article licensed under the terms of the Creative Commons Attribution Non-Commercial License (http: //creativecommons.org/licenses/by$\mathrm{nc} / 3.0 /$ ), which permits unrestricted, non-commercial use, distribution and reproduction in any medium, provided the work is properly cited. 